\title{
Activation of Spinal Glucagon-Like Peptide-1 Receptors Specifically Suppresses Pain Hypersensitivity
}

\author{
Nian Gong, Qi Xiao, Bin Zhu, Chang-Yue Zhang, Yan-Chao Wang, Hui Fan, Ai-Niu Ma, and Yong-Xiang Wang \\ King's Laboratory, Shanghai Jiao Tong University School of Pharmacy, Shanghai 200240, China
}

This study aims to identify the inhibitory role of the spinal glucagon like peptide-1 receptor (GLP-1R) signaling in pain hypersensitivity and its mechanism of action in rats and mice. First, GLP-1Rs were identified to be specifically expressed on microglial cells in the spinal dorsal horn, and profoundly upregulated after peripheral nerve injury. In addition, intrathecal GLP-1R agonists GLP-1(7-36) and exenatide potently alleviated formalin-, peripheral nerve injury-, bone cancer-, and diabetes-induced hypersensitivity states by $60-90 \%$, without affecting acute nociceptive responses. The antihypersensitive effects of exenatide and GLP-1 were completely prevented by GLP-1R antagonism and GLP-1R gene knockdown. Furthermore, exenatide evoked $\beta$-endorphin release from both the spinal cord and cultured microglia. Exenatide antiallodynia was completely prevented by the microglial inhibitor minocycline, $\beta$-endorphin antiserum, and opioid receptor antagonist naloxone. Our results illustrate a novel spinal dorsal horn microglial GLP-1R/ $\beta$-endorphin inhibitory pathway in a variety of pain hypersensitivity states.

Key words: chronic pain; GLP-1 receptor; microglia

\section{Introduction}

Glucagon-like peptide-1 (GLP-1) is a hormone secreted from L cells of the small intestine in response to food ingestion. GLP-1 facilitates glucose-dependent insulin secretion, inhibits glucagon secretion, gastric emptying, and food intake, and promotes pancreatic $\beta$-cell proliferation via activation of the GLP-1 receptor (GLP-1R) (Baggio and Drucker, 2007). GLP-1Rs belong to the Family B of G-protein-coupled receptors, and their major signal transduction is through calcium and cyclic adenosine monophosphate (cAMP)/protein kinase A signaling pathways (Holst, 2007; Ramos et al., 2008; Roger et al., 2011). GLP-1 is easily degraded by dipeptidyl peptidase-4 (DPP-4) present in plasma and other bodily fluids, such as CSF, resulting in its extremely short duration (Baggio and Drucker, 2007; Davis et al., 2010). There are two forms of GLP-1. GLP-1(7-36)-amide is the major biologically active form of GLP-1. GLP-1(7-37) is less biologically active but still detectable. Exenatide is an amidated version of exendin-4 originally identified from Gila monster saliva (Eng et al., 1992). It selectively activates GLP-1Rs and exhibits the same biological actions as GLP-1 but has a much longer duration because it is not degraded by DPP-4 (Perry et al., 2003). GLP-1 that

Received Nov. 6, 2013; revised March 9, 2014; accepted March 11, 2014.

Author contributions: N.G. and Y.-X.W. designed research; N.G., Q.X., B.Z., C.-Y.Z., Y.-C.W., H.F., and A.-N.M. performed research; N.G. and Y.-X.W. analyzed data; N.G. and Y.-X.W. wrote the paper.

This work was supported by the National Natural Science Foundation of China No. 81374000 to Y.-X.W. and No. 81202517 to A.-N.M., the Doctoral Mentor Fund No. 20110073110062 to Y.-X.W., the Ministry of Education of China and Predoctoral Fellowship to N.G., the Ministry of Education of China, Shanghai Jiao Tong University, and SJTU School of Pharmacy. We thank Dr. Pei-Zhuo Zhang at Jima Pharma Inc. (Shanghai, China) for the synthesis of the siRNA targeting GLP-1Rs and corresponding nonspecific oligonucleotides.

The authors declare no competing financial interests.

Correspondence should be addressed to Dr. Yong-Xiang Wang, King's Laboratory, Shanghai Jiao Tong University School of Pharmacy, 800 Dongchuan Road, Shanghai 200240, China. E-mail: yxwang@sjtu.edu.cn.

DOI:10.1523/JNEUROSCI.4703-13.2014

Copyright $\odot 2014$ the authors $\quad 0270-6474 / 14 / 345322-13 \$ 15.00 / 0$ is engineered with prolonged duration (Baggio and Drucker, 2007), exenatide (Göke et al., 1993), and the DPP-4 inhibitors (e.g., sitagliptin) (Davis et al., 2010) are currently marked for the treatment of Type 2 diabetes mellitus. These drugs represent one of the up and coming strategies for the treatment of Type 2 diabetes because of their lower hypoglycemic effect and reduced cardiovascular risk.

In a study to investigate glucoregulatory effects of exendins (Gong et al., 2011a), we serendipitously discovered that GLP$1(7-36)$ produced potent antinociception in the formalin test. This study aims to systemically explore the inhibitory role of the spinal GLP-1R signaling pathway in pain hypersensitivity states and its mechanism of action. The study protocols included the following: (1) identification of specific expression of GLP-1Rs on spinal dorsal horn microglia; (2) determination of the efficacy, potency, and site of exenatide and GLP-1(7-36) antinociception in a variety of animal models of pain hypersensitivity vs acute nociceptive responses; (3) clarification of the role of spinal GLP1 Rs in exenatide antinociception; and (4) demonstration of $\beta$-endorphin release from spinal microglia as a mechanism for GLP-1R agonism antinociception. Our results identify, for the first time, a novel spinal dorsal horn microglial GLP-1R/ $\beta$ endorphin pathway that specifically inhibits pain hypersensitivity states.

\section{Materials and Methods}

Chemicals and reagents. Exenatide was obtained from Kaijie BioPharmaceutical, whereas GLP-1(7-36) and exendin(9-39) were purchased from Shanghai TASH Biotechnology. Morphine hydrochloride and minocycline were purchased from Northeast Pharmaceuticals Group and Yuanye Biotech, respectively. DAPI and naloxone hydrochloride were purchased from Sigma-Aldrich. The rabbit polyclonal antibody neutralizing $\beta$-endorphin was purchased from Abcam, and EQ14 was synthesized by GL Biochem. 
The siRNA targeting the GLP-1R and its nonspecific oligonucleotide were synthesized by GenePharma, according to the designation of Yin et al. (2010). The 19 nucleotide duplex and 2 unpaired nucleotide overhanging $3^{\prime}$ 'end were as follows: GLP-1R, 5'-GUA UCU CUA CGA GGA CGA GUU-3'/5'-CUC GUC CUC GUA GAG AUA CUU-3'; and nonspecific control, 5' -UUC UCC GAA CGU GUC ACG UUU-3'/5'-ACG UGA CAC GUU CGG AGA AUU-3'. To formulate siRNAs, linear polyetherimide (PEI) of $25 \mathrm{kDa}$ (Polysciences) was dissolved in 5\% dextrose diethyl pyrocarbonate-treated water, $\mathrm{pH}$ 7.4. A total of $1 \mathrm{mg}$ RNA was dissolved in $1.5 \mathrm{mg}$ PEI in a PEI:RNA ratio of six equivalents of PEI nitrogen per RNA phosphate to form RNA-polymer complexes at room temperature for $20 \mathrm{~min}$ (Chen et al., 2012).

Primary neuronal and glia cell culture. Neurons and glial cells were isolated from the spinal dorsal horn of 1-d-old neonatal Wistar rats. Dissociated cells were suspended in DMEM supplemented with $10 \%$ $(\mathrm{v} / \mathrm{v})$ FCS and penicillin $(100 \mathrm{U} / \mathrm{ml})$ and streptomycin $(100 \mu \mathrm{g} / \mathrm{ml})$. For neuronal culture, after $1.5 \mathrm{~h}$ of incubation, the medium was changed to Neurobasal containing B27 supplement and $0.5 \mathrm{~mm}$ glutamine for further culture. All experiments were initiated 5-6 d after plating. The dendrites of the cultured neurons without staining were clearly observed under microscope and harvested neurons showed a purity $>85 \%$ as determined by neuronal nuclear antigen (NeuN) immunoreactivity. For glial cell culture, after culture for $8 \mathrm{~d}$, microglial cells were prepared as floating cell suspensions by shaking the flask at $260 \mathrm{rpm}$ for $2 \mathrm{~h}$. Aliquots were transferred to plates and unattached cells were removed by washing with serum-free DMEM. Harvested microglial cells showed a purity $>95 \%$ as determined by CD $11 \mathrm{~b}$ (OX42) immunoreactivity. After culture for $11 \mathrm{~d}$, astrocytes were prepared as floating cells suspensions by shaking flask for $2 \mathrm{~h}$ and then incubated with $10 \mathrm{ml}$ of $0.05 \%$ trypsinethylenediaminetetraacetic acid in the cell incubator for $15 \mathrm{~min}$ to separate the oligodendrocytes from the astrocytes. After trypsin neutralization with $10 \mathrm{ml}$ complete media, the floating cell suspensions were discarded. A nearly intact layer of astrocytes in the bed layer was then trypsinized and subcultrued conventionally. Prepared astrocytes showed a purity $>90 \%$ as determined by GFAP immunoreactivity.

RNA extraction, reverse transcription, and real-time quantitative PCR. RNA extraction, reverse transcription, and real-time quantitative PCR were performed as described by Chen et al. (2012). The spinal lumbar enlargements were collected and mechanically homogenized using electronic microhomogenizer at $4000 \mathrm{rpm}$ for $10 \mathrm{~s}$ in TRIzol on ice. Total RNA of the spinal lumbar enlargements was purified from individual sample by use of the TRIzol reagent. Real-time quantitative PCR was performed with Mastercycler ep realplex (Eppendorf) using RealmasterMix (SYBR Green I). Primers were as follows: $5^{\prime}$-CCA AGG TCA TCC ATG ACA AC-3' ( gapdh forward), 5' -TCC ACA GTC TTC TGA GTG GC-3' (gapdh reverse), 5'-ACG CAC TTT CTT TCT CTG CC-3' (GLP-1R forward), 5'-CAA ACA GGT TCA GGT GGA TG-3' (GLP-1R reverse) (Vahl et al., 2007). All primers were chemically synthesized by United Gene. Amplification of the housekeeping gene gapdh was measured for each sample as an internal control for sample loading and normalization.

Western blotting. Western blotting was performed as described by Chen et al. (2012). The spinal lumbar enlargements or other tissues were homogenized and lysed with the ratio of 1:10 $(\mathrm{m} / \mathrm{v})$ in a radioimmunoprecipitation analysis buffer with phenylmethylsulfonyl fluoride. The homogenate was centrifuged for $5 \mathrm{~min}$ at $12,000 \mathrm{rpm}$ at $4^{\circ} \mathrm{C}$. The proteins were separated by SDS-PAGE (12\%) and then transferred to a polyvinylidene fluoride membrane by an electrophoretic method. The membrane was blocked in $8 \%$ skim milk powder in PBS containing $0.1 \%$ Tween 20 at room temperature for $1 \mathrm{~h}$, and incubated with primary antibody raised against GLP-1R (ab39072, 1:600, rabbit polyclonal, Abcam) and GAPDH (1:1500, rabbit polyclonal, Protein Tech Group) or $\beta$-actin (1:1000, rabbit polyclonal, Protein Tech Group) simultaneously at $4^{\circ} \mathrm{C}$ for $12 \mathrm{~h}$. Protein bands were visualized using secondary antibody (IRDye 800-conjugated affinity purified goat anti-rabbit IgG; Rockland), with the Odyssey Infrared Imaging system from Li-Cor Biosciences. The band intensity was quantitated using a computer-assisted image analysis program (ImageJ Software, National Institutes of Health). To control sampling errors, the GLP-1R/GAPDH or GLP-1R/ $\beta$-actin band intensity ratio was obtained to quantify relative protein expression levels.

Immunofluorescence staining. Single and double immunofluorescence labeling of GLP-1 receptors and/or microglia, astrocytes, and neurons was performed and observed on spinal cord sections and cultured cells using a Confocal microscope (TCS SP8, Leica Microsystems). Rats were anesthetized by pentobarbital injection $(50 \mathrm{mg} / \mathrm{kg}$ ) and intracardially perfused with $500 \mathrm{ml}$ normal saline followed by $300 \mathrm{ml}$ of $4 \%$ PFA (w/v) in PBS. Spinal lumbar enlargements were collected and fixed in $4 \%$ buffered PFA at $4^{\circ} \mathrm{C}$ for $12 \mathrm{~h}$ and cut into $20-\mu \mathrm{m}$-thick frozen sections (Gong et al., 2013). For spinal microglia, astrocytes and neurons from the neonatal rats, cells were placed in 6 -well plates $\left(5 \times 10^{4}\right.$ cells/well $)$ with poly-L-lysine-coated coverslips at the bottom and were fixed in 4\% PFA. Both frozen sections and flasks were incubated in $10 \%$ goat serum $(\mathrm{v} / \mathrm{v})$ and $0.5 \%$ Triton X-100 (v/v) in PBS for $1 \mathrm{~h}$. Frozen sections and flasks were incubated with the human and rat GLP-1R antibody (ab119287, rabbit polyclonal, 1:100 for tissue sections, 1:200 for cell flasks, Abcam) and/or other appropriate primary antibodies for $24 \mathrm{~h}$ at $4^{\circ} \mathrm{C}$. Spinal neuronal and glial cells were identified by the following markers: NeuN (1:60 for tissue sections or 1:100 for cell flasks, mouse polyclonal, MAB377; Millipore) for mature neurons, OX42 (1:100 for tissue sections or 1:200 for cell flasks, mouse polyclonal, ab1211; Abcam) for microglia and GFAP (1:100 for tissue sections or 1:200 for cell flasks, mouse polyclonal, MAB360; Millipore) for astrocytes. The anti-GFAP antibody (Nakamura et al., 2013), the anti-NeuN antibody (Lindia et al., 2005; Morgado et al., 2011), and the anti-OX42 antibody (Avila-Martin et al., 2011) have been used by other laboratories. All antibodies were tested for optimal dilution and nonspecific staining. The GLP-1R was visualized with the Alexa-555-conjugated goat anti-rabbit secondary antibody (1: 200, Invitrogen). Other antibodies were detected with the Alexa-488conjugated goat anti-mouse secondary antibody (1:200, Invitrogen). DAPI staining was also used to determine cell nuclei.

Quantification of the GLP-1R and OX42/GFAP/NeuN-immunopositive cell profiles in the spinal cord (Gong et al., 2013). For quantity measurement of immunofluorescent intensity, photomicrographs of the medial three-fourths of the superficial dorsal horn (laminas I-V) were captured under a $5 \times$ magnification. Positively stained surface area was measured using a computer-assisted image analysis program (ImageJ Software, National Institutes of Health) after low and high thresholds were set to exclude background fluorescence and include immunofluorescent intensity measurements only from positively stained cell surfaces. The same threshold value configuration was used to measure all surface areas in each experimental group at the same time. The measured areas were transferred to Excel automatically and calibrated standardization. A standardized field area was sampled from regions within arbitrarily selected three nonadjacent dorsal horn sections. The GLP-1R and OX42/ GFAP/NeuN-immunolabeled surface areas were measured in laminae $\mathrm{I}-\mathrm{V}$ of the spinal dorsal horn by a researcher blinded to the experimental conditions. The averaged percentage immunolabeled surface area was the fraction of the positive immunofluorescent surface area of total measured picture area from 3 sections of each spinal cord. Data were then calculated from 5 or 6 rats from each group. It is noted that the current protocol used for the quantification of the GLP-1R and OX42/GFAP/ NeuN-immunopositive cells was conventionally profile-based rather than stereologically unbiased based. Although the method may initiate some systematic bias in absolute numbers, it may not significantly affect our conclusion as we were interested to find out whether there was a relative and significant difference in numbers between sham and peripheral nerve injury groups (Saper, 1996).

$\beta$-Endorphin measurement. $\beta$-Endorphin concentrations in the spinal cord homogenates and culture medium were determined using an enzyme-linked fluorescent immunoassay kit (Phoenix Pharmaceuticals) that was validated by running linear standard curves with testing samples same time for determination of the peptide concentration. The crossactivity of the assay included $\alpha$-endorphin (100\%) and $\gamma$-endorphin $(60 \%)$, but not methionine-enkephalin $(0 \%)$ or leucine-enkephalin $(0 \%)$, according to the manufacture's information. For the spinal cord homogenates, rat ipsilateral spinal lumbar enlargements were taken from sham and neuropathic rats, and homogenized (4000 rpm) for $15 \mathrm{~s}$ with a 
homogenizer (Fluko Equipment) in $10 \mathrm{~mm}$ Tris- $\mathrm{HCl}(1 \mathrm{~g}$ tissue $/ 5 \mathrm{ml})$ and centrifuged $(4000 \mathrm{rpm})$ at $4^{\circ} \mathrm{C}$ for $15 \mathrm{~min}$. The protein content was measured using a standard bicinchoninic acid protein assay (Beyotime Institute of Biotechnology). Primary cultured neurons, astrocytes, and microglia were placed in 24 -well plates $\left(1 \times 10^{5}\right.$ cells/well $)$ and washed twice with $1 \mathrm{ml}$ warm DMEM containing $2 \mathrm{mg} / \mathrm{ml} \mathrm{BSA}$ and $15 \mathrm{mmol} / \mathrm{L}$ $\mathrm{N}$-(2-hydroxyethyl)piperazine- $\mathrm{N}^{\prime}$-2-ethanesulfonic acid. Cells were exposed to $10^{-8} \mathrm{M}$ exenatide for $2 \mathrm{~h}$, and supernatant samples were processed. The $\beta$-endorphin levels of the homogenates and cultural supernatant samples were then measured by using the fluorescent assay.

Animal procedures. All experiments were performed in accordance with the Animal Care and Welfare Committee of Shanghai Jiao Tong University School of Pharmacy and followed the animal care guidelines of the National Institutes of Health. All efforts were made to reduce the number of animals used, to minimize their suffering, and to use alternatives to in vivo techniques, if available. Male Swiss mice (20-25 g, 6-8 weeks old), and male and female Wistar rats (180-250 g, 8-10 weeks old) were obtained from the Shanghai Experimental Animal Institute for Biological Sciences and housed in a temperature- and humidity-controlled environment on a $12 \mathrm{~h}$ light/dark cycle (lights on at 7:00 A.M.) with food and water ad libitum. Animals were acclimated to the laboratory environment for 3-5 d before entering the study. Experimental study groups ( $n=5$ or 6 in each group) were assigned randomly, and the researcher was blind for behavior testing.

Intrathecal and intracerebroventricular catheterization and injection in rats. Intrathecal catheterization and injection were conducted as described by Gong et al. (2011b). A $24 \mathrm{~cm}$ polyethylene catheter (PE-10: $0.28 \mathrm{~mm}$ i.d. and $0.61 \mathrm{~mm}$ o.d., Clay Adams) with volume of $\sim 13 \mu \mathrm{l}$ was inserted into the rat lumbar level of the spinal cord as described previously (Gong et al., 2011b) under inhaled isoflurane anesthesia (4\% for induction and $1 \%$ for maintenance) run by an anesthesiameter (Ugo Basile Gas Anesthesia System). Two days after recovery from anesthesia, the correct intrathecal cannula placement was verified by administering $4 \%$ lidocaine ( $10 \mu \mathrm{l}$ followed by $15 \mu \mathrm{l}$ of saline for flushing) with a $50 \mu \mathrm{l}$ microinjector (Shanghai Anting Micro-Injector Factory). The lidocaine test was performed 5-7 d before the start of the drug testing sessions. Only rats that had no motor impairment after intrathecal catheter were considered for the study; only rats that developed immediate bilateral paralysis of hind limbs after intrathecal administration of lidocaine were selected for the study. For intrathecal administration, the drugs were microinjected with a $50 \mu \mathrm{l}$ microinjector in a volume of $10 \mu \mathrm{l}$ followed by a saline flush in a volume of $15 \mu$ l. The methods for intracerebroventricular catheterization and injection in Wistar rats (weighting 250-270 g) were described by Lu et al. (2012). Briefly, animals were anesthetized by intraperitoneal injection of pentobarbital sodium $(50 \mathrm{mg} / \mathrm{kg})$ and placed on a stereotaxic apparatus (Stoelting). After exposing the skull of the rat, a 24-gauge guide cannula $(0.55 \mathrm{~mm})$ was stereotaxically implanted $3 \mathrm{~mm}$ above the right lateral ventricle (anteroposterior: $-1.1 \mathrm{~mm}$ from bregma; mediolateral: $1.5 \mathrm{~mm}$; dorsoventral: $2.8 \mathrm{~mm}$ below the surface of the skull). The guide cannula was anchored to two stainless-steel screws using dental acrylic. The guide cannula was kept viable with a dummy cannula, which was removed daily and cleaned during the handling procedure. Animals were allowed to recover for at least $7 \mathrm{~d}$ before undergoing behavioral testing. Drugs were slowly infused using a 30-gauge cannula extended $1 \mathrm{~mm}$ beyond the guide cannula and connected to a 10 $\mu \mathrm{l}$ microsyringe via a polyethylene tube, which remained in place for $30 \mathrm{~s}$ to allow for diffusion. Each rat was intraventricularly injected with $5 \mu \mathrm{l}$ Indian ink dye after the experiment to ensure accurate and complete of surgical operation.

Rat formalin, tail-flick, hotplate, and rotarod tests and mouse formalin tests. Formalin test was performed in both mice and rats that were acclimated individually to the observation cage for $30 \mathrm{~min}$ before testing. The mouse formalin test was performed, as previously described (Gong et al., 2012 , 2013). Briefly, $10 \mu \mathrm{l}$ of $5 \%$ formalin in $0.9 \%$ saline was subcutaneously injected on the dorsal side of the right hindpaw, and the animal was immediately placed in a transparent polycarbonate box. The duration of nociceptive behaviors (licking/biting) was manually quantified in the pooled durations at $0-5 \mathrm{~min}$ and $20-40 \mathrm{~min}$, which was considered as the acute nociceptive response and tonic flinching response, respectively.
The rat formalin test was performed as previously described (Gong et al., 2011b, 2013) with slight modifications, by injecting $50 \mu \mathrm{l}$ of $1 \%$ or $5 \%$ formalin in normal rats or $0.2 \%$ formalin in diabetic rats as specifically indicated subcutaneously on the dorsal side of the left hindpaw, and the rats were immediately placed in $23 \mathrm{~cm} \times 35 \mathrm{~cm} \times 19 \mathrm{~cm}$ transparent polycarbonate boxes. Nociceptive behavior was manually quantified by combining the number of the formalin-injected paw flinches in $1 \mathrm{~min}$ epochs. Measurements were taken at $10 \mathrm{~min}$ intervals beginning immediately after formalin injection and ending $90 \mathrm{~min}$ later.

The tail-flick and hotplate tests were subsequently performed with the same animals according to the previous description with modifications (Gong et al., 2012, 2013). The model SSY-H digital display thermostatic water-bath (Shanghai Sanshen Medical Instrument) was used to maintain a constant water temperature of $50 \pm 0.5^{\circ} \mathrm{C}$. While the rats were placed in a tubular restrainer, their tails were immersed $3.5 \mathrm{~cm}$ in the water bath as described previously. The nociceptive threshold was defined as the time required to elicit a flick of the tail. The cutoff time was $30 \mathrm{~s}$ for tail-flick measurements to minimize tissue injury. Nociceptive reflexes in response to thermal stimulus in the hotplate test were measured using YLS-6B Intelligence Hot Plate Analgesia Meter (Shandong Academy of Medical Sciences Device Station). The surface of the hotplate was heated to a constant temperature at $55 \pm 0.1^{\circ} \mathrm{C}$, as measured by a built-in digital thermometer with an accuracy of $0.1^{\circ} \mathrm{C}$ and verified by a surface thermometer. Rats were placed on the hotplate, which was surrounded by a clear acrylic cage, and the start/stop button on the timer was activated. The latency to respond with a hindpaw lick was measured to the nearest $0.1 \mathrm{~s}$ by deactivating the timer when the response was observed. Trials were terminated if the animals did not respond within $50 \mathrm{~s}$ to avoid tissue damage.

Motor coordination performance was assessed by means of an YLS-4C Rota Rod with automatic timers and falling sensors (Yiyan Scientific) (Gong et al., 2011b). The rats were trained and tested by using an accelerated speed from 5 to $25 \mathrm{rpm}$ within 1 min followed by $25 \mathrm{rpm}$ for 2 more minutes. The accumulated time (seconds $/ 3 \mathrm{~min}$ ) for animals to spend on the Rota Rod was recorded during the 3 min observation period after the animals were trained once a day each for $9 \min$ for $3 \mathrm{~d}$. The accumulated time spent on the Rota Rod was at least $120 \mathrm{~s}$ to allow for inclusion in the study. For the last test, the accumulated time (seconds/5 min) spent on the Rota Rod was recorded during the 5 min observation after receiving control or test articles.

Rat models of bone cancer pain and neuropathic pain. For the rat model of bone cancer pain, female Wistar rats were anesthetized by sodium pentobarbital $(50 \mathrm{mg} / \mathrm{kg}$, intraperitoneally). Bilateral superficial incisions were made in the skin overlying the patella after disinfecting with $70 \%$ ethanol. More incisions were cut along the patellar ligament to expose the tibia head with minimal damage. A 23-gauge needle was inserted at the site of intercondylar eminence and pierced $7 \mathrm{~mm}$ below the knee joint into the medullary cavity of tibia. The needle was then removed and replaced with a 29 -gauge needle attached to a $25 \mu \mathrm{l}$ microsyringe (Shanghai Anting Micro-Injector Factory). A total of $4 \times 10^{5}$ Walker 256 carcinoma cells in $10 \mu$ l PBS were slowly injected into the left tibia cavity. Simultaneously, $10 \mu \mathrm{l}$ PBS was injected into the right tibia cavity in all these rats. The syringe was left in place for an additional $2 \mathrm{~min}$ to prevent the carcinoma cells from leaking out along the injection track. The injection site was closed using bone wax while the syringe was removed. The wound was then closed and dusted with penicillin powder after closure of the injection site (Mao-Ying et al., 2006; Huang et al., 2012).

For the rat model of neuropathic pain, male Wistar rats were anesthetized under inhale isoflurane anesthesia ( $4 \%$ for induction and $1 \%$ for maintenance) run by an anesthesiameter (Ugo Basile Gas Anesthesia System). The rat's back was shaved, and the left lumbar paravertebral region was exposed. After subperiosteal removal of sixth lumbar transverse process, both the left L5 and L6 spinal nerves were isolated and tightly ligated with 6-0 silk suture. After ligation, the lumbar fascia was closed by 4-0 resorbable polyglactin suture. The skin was then dusted with penicillin powder and sutured, and the rats were allowed to recover. Sham surgery consisted of an identical procedure, except that the nerves were not ligated after exposure. Of the nerve-ligated rats, only those with 
marked unilateral allodynia to mechanical stimulation (hindlimb withdrawal thresholds in the operated side $<8 \mathrm{~g}$ ) and with no major motor impairment were selected for further studies (Kim and Chung, 1992; Zhao et al., 2010).

Rat model of diabetic pain. The rats were fasted for $14 \mathrm{~h}$ before receiving intravenous single injection of streptozocin ( $50 \mathrm{mg} / \mathrm{kg}$, Sigma) (Courteix et al., 1993; Gong et al., 2011a). High blood sugar levels were observed on and after the third day after injection. Mechanical allodynia and $0.2 \%$ formalin allodynia were measured $30-50 \mathrm{~d}$ after streptozocin injection by electrical von Frey hairs (see the below mechanical allodynia measurement) and flinch counting (see the above formalin test), respectively.

Behavioral assessment of mechanical allodynia. Behavioral assessment of mechanical allodynia was conducted as described by Huang et al. (2012). The hindlimb withdrawal threshold evoked by stimulation of the hindpaw with a 2290 CE electrical von Frey hair (IITC Life Science) was determined while the rat stood on a metal grid. The monofilament, which produced forces ranging from 0.1 to $65 \mathrm{~g}$, was applied to the foot pad with increasing force until the rat suddenly withdrew its hindlimb. The lowest force producing a withdrawal response was considered the threshold, which was based on three repeated measurements.

Statistical analysis. For the dose-response curve analysis, the parameters, i.e., minimum effect $\left(\mathrm{E}_{\min }\right)$, maximum effect $\left(\mathrm{E}_{\max }\right)$, half-effective dose $\left(\mathrm{ED}_{50}\right)$, and Hill coefficient $(n)$, were calculated from individual dose-response curves using a program (GraphPad Prism, Version 5.01, GraphPad Software). To determine the parameters of dose-response curves, values of response $(Y)$ were fitted by nonlinear least-squares curves to the relation $Y=a+b x$, where $x=[D]^{n} /\left(E D_{50}{ }^{n}+[D]^{n}\right)$, to give the value of $\mathrm{ED}_{50}$ and $b\left(\mathrm{E}_{\max }\right)$ yielding a minimum residual sum of squares of deviations from the theoretical curve (Wang and Pang, 1993).

The results are expressed as mean \pm SEM or $95 \%$ confidence limits, and there were no data missing. Statistical significance was evaluated by an unpaired or paired Student's $t$ test, or a one-way or repeated measures two-way ANOVA by using Prism. Post hoc Student-Newman-Keuls test was followed when a statistically significance of the drug (dose) effect (one-way ANOVA, factor is drug (dose)) or the drug (dose) $\times$ time interaction (repeated measures two-way ANOVA, factors are drug (dose), time and their interaction) was observed. Probability values were two-tailed, and the statistical significance criterion $p$ value was 0.05 .

\section{Results}

\section{GLP-1Rs are expressed in the spinal cord}

GLP-1Rs are distributed in various tissues, including the pancreatic islets, epithelial cells of trachea-bronchial, brain, and dorsal root ganglia, but not in the skeletal muscle (VillanuevaPeñacarrillo et al., 1995; Bullock et al., 1996; Alvarez et al., 2005; Tornehave et al., 2008; Himeno et al., 2011; Teramoto et al., 2011). However, there have been controversial findings on GLP-1R expression in the spinal cord (Vahl et al., 2007; Li et al., 2012). In an effort to examine whether GLP-1Rs were expressed in the spinal cord, we first validated the specificity of the commercial GLP-1R antibody. It has been shown that rat PC12 cells express GLP-1Rs (Perry et al., 2002), whereas HEK293T cells do not (Beinborn et al., 2005; Syme et al., 2006; Coopman et al., 2010). Our immunostaining demonstrated that the GLP-1R antibody was specifically labeled with HEK293 cells that stably express human GLP-1Rs (Fig. $1 A, B$ ) and PC12 cells (Fig. 1C,D), but not with HEK293T cells (Fig. 1E,F).

The spinal cord, cortex, hippocampus, dorsal root ganglia, pancreatic islets, and skeletal muscle obtained from normal rats were coimmunostained with the GLP-1R and GADPH antibodies. Our images showed that GLP-1Rs were specifically expressed in the superficial spinal dorsal horn (Fig. $1 G$ ), as well as the cortex (Fig. $1 H$ ), hippocampus (Fig. $1 I$ ), dorsal root ganglia (Fig. $1 J$ ), and pancreatic islets (Fig. $1 K$ ), but not the skeletal muscle (Fig. $1 L$ ). The specificity of the GLP-1R antibody was further validated by the above negative immunostaining of the skeletal muscle and the preventive effect of the antigenic peptide EQ14 in the spinal cord. The human and rat GLP-1R antibody was generated using an immunogenic peptide (PWASSVLQGHVYRFCTAEGIWLHKDNSSLPWRDLSECEESKQGERNSPEEQ) of the amino acid sequence of 90-140 from GLP-1R; the sequence is conserved for both the human and rat. EQ14, a smaller 14-amino acid antigen peptide with amino acid sequence of EESKQGERNSPEEQ-OH from the original antigen peptide, was selected based on the high antigenic score of 0.87 . As shown in Figure $1 M-P$, EQ14 completely prevented GLP-1R immunostaining in the spinal cord.

We further quantitatively measured GLP-1R expression in the spinal cord by using Western blotting compared with the cortex, hippocampus, and dorsal root ganglia as positive controls and the skeletal muscle as a negative control. As expected, GLP-1R protein was banded at $\sim 53 \mathrm{kDa}$ detected in the cortex, hippocampus, and dorsal root ganglia. GLP-1R protein was clearly detected in the spinal cord, with a similar level to the cortex and hippocampus but a higher level than the dorsal root ganglia. In contrast, GLP-1R expression was not detectable in the skeletal muscle (Fig. $2 A, B)$.

\section{GLP-1Rs specifically expressed on spinal microglia are upregulated after peripheral nerve injury}

We then examined differential distribution of GLP-1Rs in the spinal cords from sham and neuropathic rats. In sham rats, GLP-1R immunofluorescence staining was widely expressed throughout the white and gray matter of the spinal cord. GLP$1 \mathrm{R}$-immunopositive fluorescence was present on smaller oligodendrocytes and radial oligodendrocytes in the white matter, and bigger motor neurons in the ventral horn. In the dorsal horn, it was widely present on relatively smaller cells in the I-V laminae (Fig. 2C), in agreement with a previous study using the GLP-1R messenger RNA in situ hybridization method (Merchenthaler et al., 1999). Immunofluorescence was also stained with the microglial marker OX42 (Fig. 2D), astrocytic marker GFAP (Fig. 2E), and the mature neuronal marker NeuN (Fig. 2F). Microglial cells were widely distributed in the spinal dorsal horn I-V laminae in an adjacent, nonoverlapping pattern close to that of GLP-1R expression (Fig. 2C,D).

Peripheral nerve injury significantly upregulated GLP-1R expression in the ipsilateral dorsal horn I-V laminae compared with the contralateral side (Fig. 2G). Consistent with previous findings in the literature, peripheral nerve injury reactivated spinal dorsal horn microglia reflected by increased OX42 fluorescence staining and hypertrophic morphology in the ipsilateral dorsal horn (Gwak and Hulsebosch, 2009) (Fig. 2H); there were also moderate proliferation in astrocytes (Gwak and Hulsebosch, 2009) (Fig. $2 I$ ) and a slight reduction in NeuN-immunopositive neurons presumably because of apoptosis (Maione et al., 2002; Scholz et al., 2005) (Fig. 2J). Upregulation of GLP-1R expression was further quantified using a computer-assisted image quantification program. After peripheral nerve injury, the averaged percentage immunolabeled surface area for GLP-1Rs in the ipsilateral side was increased by $78 \%$ compared with contralateral side (Fig. $2 \mathrm{~K}$ ). Ipsilateral expression of microglial, astrocytic, and neuronal markers was upregulated by approximately threefold (Fig. $2 L$ ) and $30 \%$ (Fig. $2 M$ ), and downregulated by $23 \%$ (Fig. $2 N$ ), respectively, compared with the contralateral side.

To identify cell types that specifically express GLP-1Rs in the spinal dorsal horn, we performed double immunofluorescence labeling of GLP-1Rs with cell-specific markers. In both sham and neuropathic rats, GLP-1R immunofluorescence was colabeled 

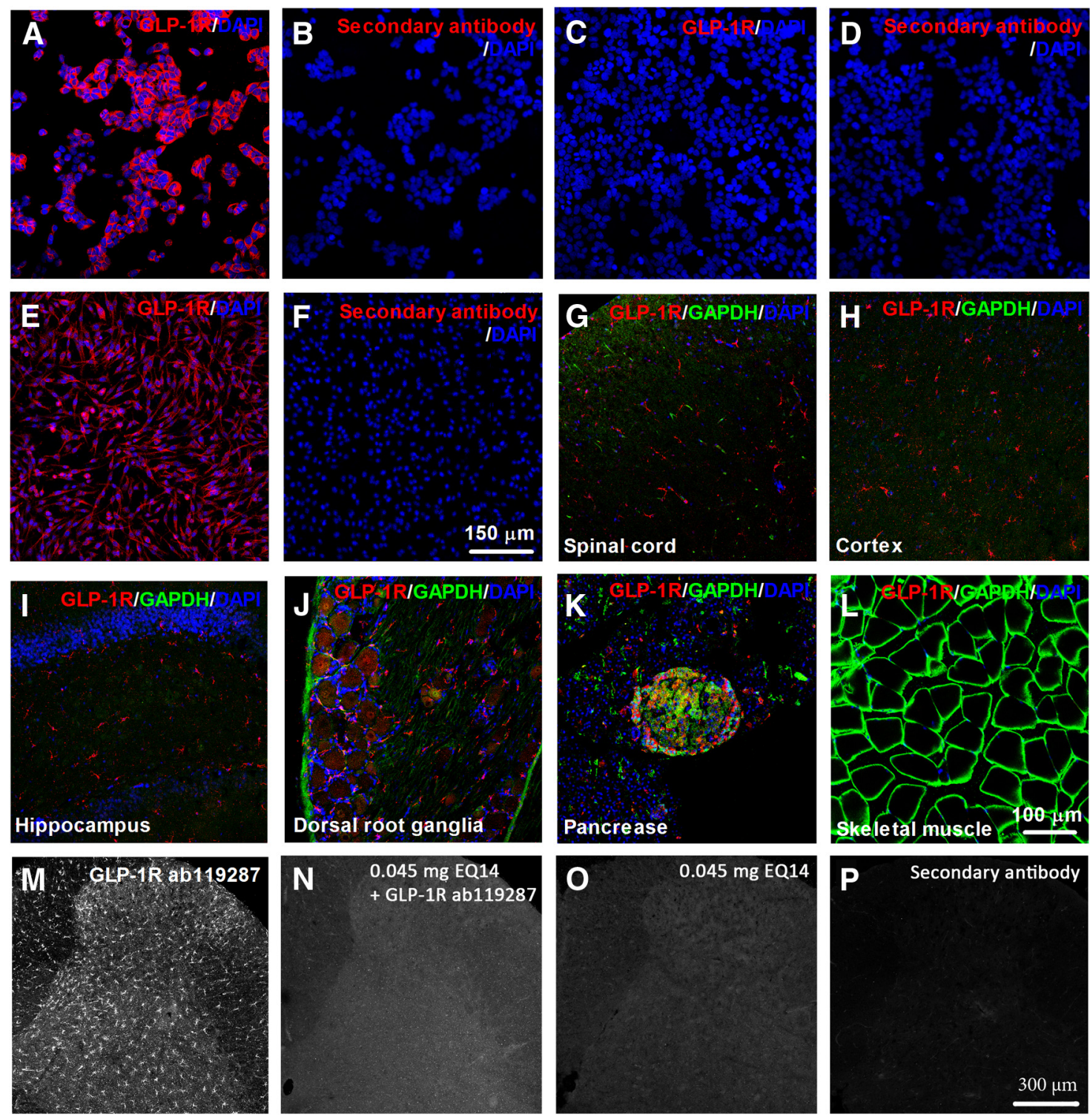

Figure 1. Representative photomicrographs of GLP-1R expression in HEK293 cells stably expressing human GLP-1Rs $(\boldsymbol{A}, \boldsymbol{B})$, HEK293T cells that do not express GLP-1Rs (C, $\boldsymbol{D}), \mathrm{PC} 12$ cells expressing rat GLP-1Rs $(\boldsymbol{E}, \boldsymbol{F})$, and their corresponding negative controls of the secondary antibody $(\boldsymbol{B}, \boldsymbol{D}, \boldsymbol{F})$, as well as the superficial spinal dorsal horn (laminae I-III; $\boldsymbol{G})$, cortex $(\boldsymbol{H})$, hippocampus $(\boldsymbol{I})$, dorsal root ganglia $(\boldsymbol{J})$, pancreatic islets $(\boldsymbol{K})$, and skeletal muscle $(\boldsymbol{L})$ from 6 normal rats. Tissues were doubly labeled with the GLP-1R and GAPDH antibodies. DAPI staining was also used to determine cell nuclei. Representative photomicrographs for the preventive effect of the GLP-1R antigenic peptide EQ14 on GLP-1R immunoreactive fluorescence staining in the spinal cords from 6 spinal nerve ligation-induced neuropathic rats. $M$, Specific fluorescence staining with the GLP-1R antibody alone. $N$, Fluorescence staining with the GLP-1R antibody in the presence of EQ14. $\mathbf{O}$, Fluorescence staining with EQ14 alone. $\boldsymbol{P}$, Negative control of the secondary antibody. Scale bars: $\boldsymbol{A}-\boldsymbol{F}, 150 \mu \mathrm{m} ; \mathbf{G}-\boldsymbol{L}, 100 \mu \mathrm{m} ; \boldsymbol{M}-\boldsymbol{P}$, $300 \mu \mathrm{m}$.

with OX42 on microglia in a lattice-like shape in the I-V laminae of the dorsal horn (Fig. $3 A-C$ ). Double immunofluorescence of GLP-1Rs with OX42 was significantly upregulated after peripheral nerve injury (Fig. 3B). In contrast, GLP-1Rs were not colabeled with GFAP on astrocytes or NeuN on neurons in the spinal dorsal horn (Fig. 3D-I). To further confirm specific expression of GLP-1Rs on microglia, spinal neuronal and glial cells were isolated from the spinal dorsal horn of neonatal rats. GLP-1Rs were colabeled with OX42 on microglial cells, with a doubleimmunopositive rate of $\sim 100 \%$ (Fig. $3 J$ ). GLP-1R immunofluorescence was not colabeled with GFAP on astrocytes (Fig. $3 K$ ) or NeuN on neurons (Fig. $3 L$ ). Our results indicate that spinal GLP1 Rs are specifically expressed on microglial cells, and upregulated accompanying microglial proliferation and hypertrophy after peripheral nerve injury.
Exenatide and GLP-1 are specifically effective in alleviating pain hypersensitivity states

The antinociceptive effect of GLP-1(7-36) was first examined in the formalin test. Paw subcutaneous injection of formalin in saline control rats produced a characteristic biphasic flinching response consisting of an initial and rapidly decaying acute phase followed by a slowly rising and long-lived tonic phase. As shown in Figure $4 A$, intrathecal injection of GLP-1(7-36) $(1,3,10,30$, or $100 \mathrm{ng}$ ) potently reduced formalin-induced tonic flinching response but not acute nociceptive response. The inhibitory effect of GLP-1(7-36) on tonic flinching response was dose-dependent with the maximum inhibition $\left(\mathrm{E}_{\max }\right)$ of $60.0 \%$ and half-effective dose $\left(\mathrm{ED}_{50}\right)$ of $2.9 \mathrm{ng}(0.9 \mathrm{pmol}, 95 \%$ confidence intervals: $2.4-$ $3.6 \mathrm{ng}$ ) (Fig. 4B). Injected intrathecally, exenatide (1, 3, 10, 30, or $100 \mathrm{ng}$ ) also exhibited the same dose-dependent antinociception 
A

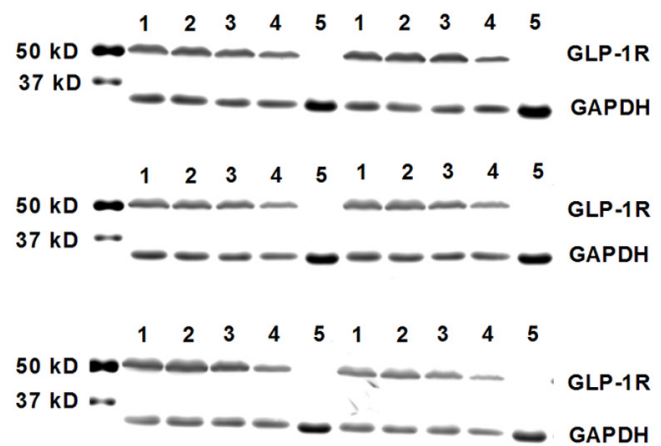

B
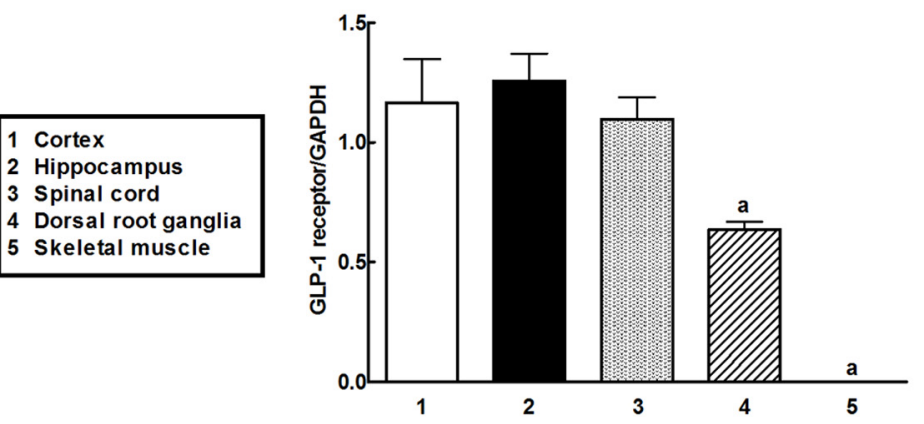
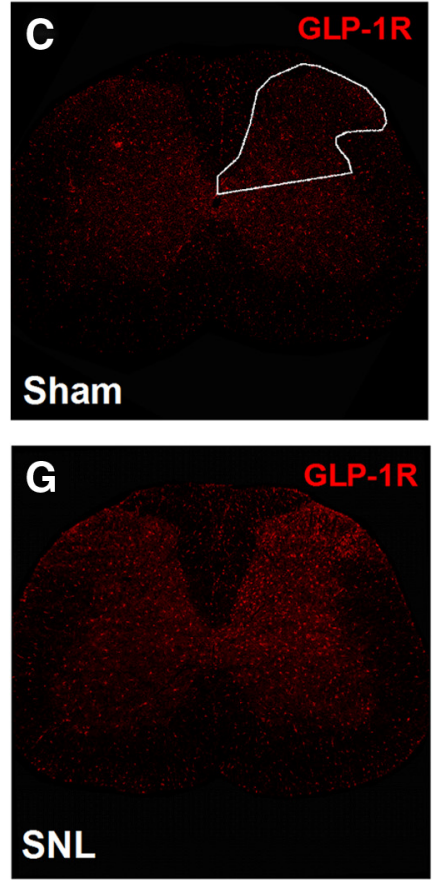

K

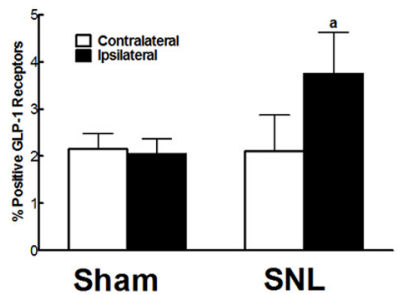

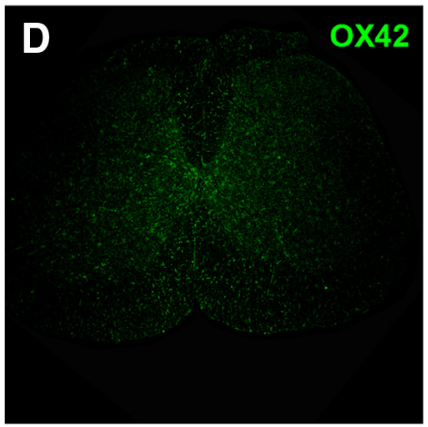
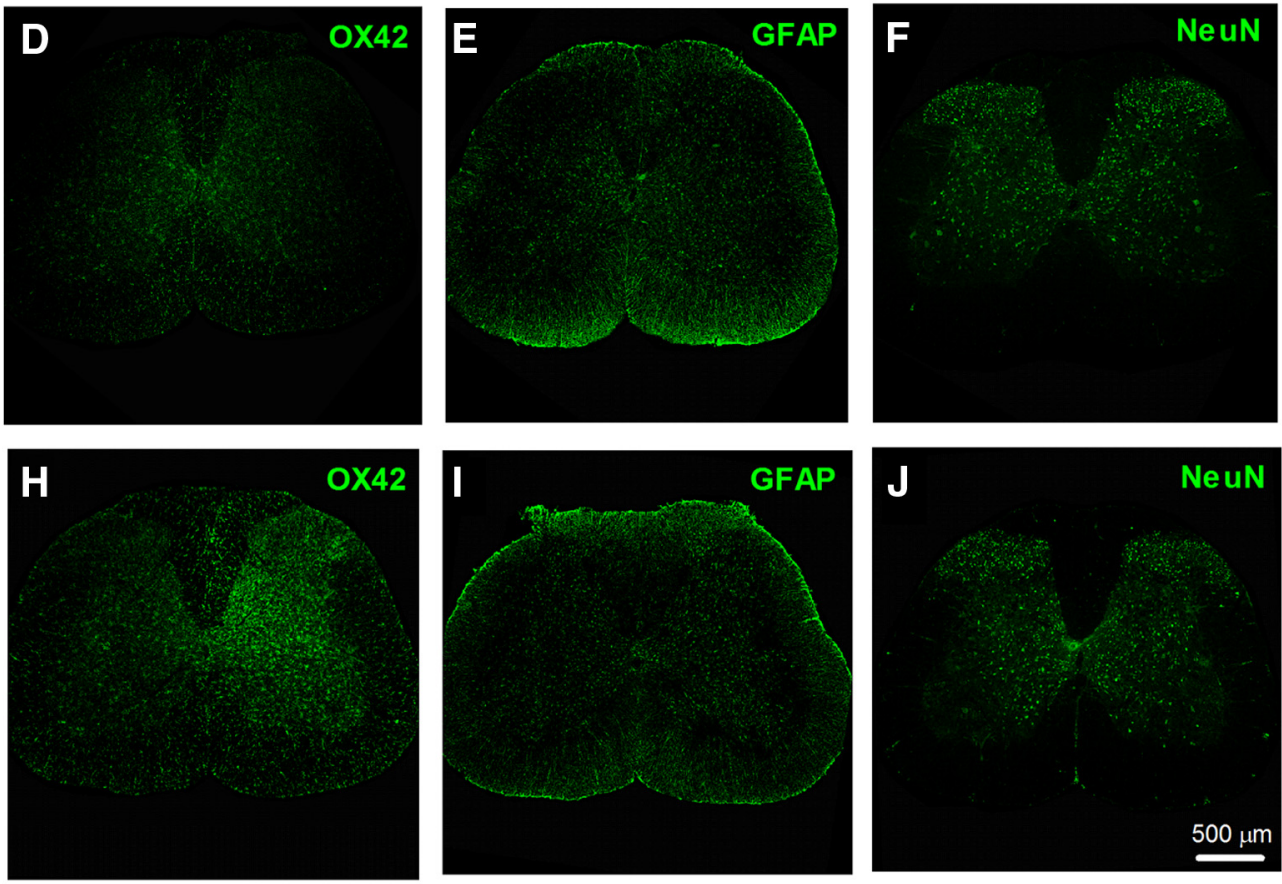

$\mathbf{L}$

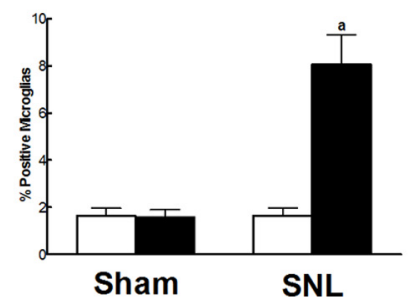

M

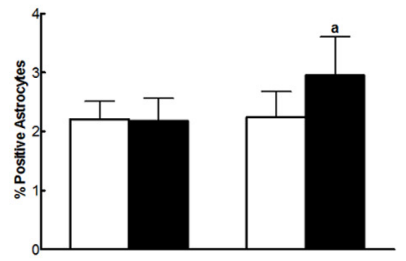

Sham

SNL
N

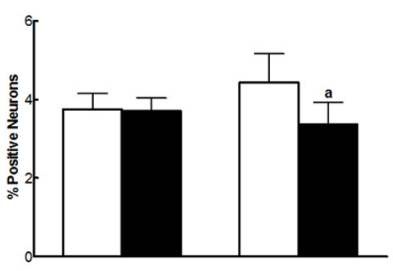

Sham

SNL

Figure 2. Expression of GLP-1Rs in the spinal cord, cortex, hippocampus, dorsal root ganglia, and skeletal muscle of normal rats by Western blotting where the GAPDH protein was used as loading control: representative gel $(\boldsymbol{A})$ and GLP-1R/GAPDH band intensity ratio $(\boldsymbol{B})$. Upregulation of GLP-1R immunostaining specifically expressed on microglia in the spinal dorsal horn after peripheral nerve injury. Photomicrographs were taken from the spinal cords in sham and neuropathic rats. Peripheral neuropathy was induced by unilateral $L 5-L 6$ spinal nerve ligation, and frozen sections were obtained from the spinal lumbar enlargements 2 weeks after surgery. Immunofluorescence was labeled with the GLP-1R antibody $(\mathbf{C}, \mathbf{G})$, microglial marker $(D 11 b(0 X 42)(\boldsymbol{D}, \boldsymbol{H})$, astrocytic marker GFAP $(\boldsymbol{E}, \boldsymbol{I})$, and mature neuronal marker NeuN $(\boldsymbol{F}, \boldsymbol{J})$. GLP-1R-(K) and OX42 (L)/GFAP $(\boldsymbol{M}) / \operatorname{NeuN}(\boldsymbol{N})$-immunolabeled surface areas were quantified from the spinal dorsal horn (laminae I-V; as indicated in () using the ImageJ computer program. The averaged percentage immunolabeled surface area was the fraction of the positive immunofluorescent surface area of total measured area in the picture from 3 sections of each spinal cord. Scale bars: $500 \mu \mathrm{m}$. Data are mean \pm SEM ( $n=5$ or 6 in each group). a Statistically significant difference from the spinal cord group in $\boldsymbol{B}$ ( $p<0.05$ by one-way ANOVA followed by post hoc Student-Newman-Keuls test) or the contralateral dorsal horns in $\boldsymbol{K}-\boldsymbol{N}(p<0.05$ by paired Student's $t$ test).

in formalin-induced flinching response (but not acute nociceptive response) (Fig. $4 C$ ), with a slightly smaller $\mathrm{ED}_{50}$ value of $2.5 \mathrm{ng}(0.6 \mathrm{pmol}, 95 \%$ confidence intervals: $0.9-6.8 \mathrm{ng})$ and greater $\mathrm{E}_{\max }$ of $69.4 \%$ (Fig. $4 B$ ). In contrast, intracerebroventricular injection of exenatide up to $300 \mathrm{ng}$ was not effective in alleviating either formalin-induced acute or tonic flinching response (Fig. 4D).
Tibia implantation of cancer cells produced progressive mechanical allodynia in rats $\sim 15 \mathrm{~d}$ after surgery. Intrathecal exenatide $(3,10,30,100$, or $300 \mathrm{ng})$ long-lastingly and reversibly blocked bone cancer-induced mechanical allodynia in ipsilateral paws with the peak effect at $0.5 \mathrm{~h}$ and the duration longer than $4 \mathrm{~h}$ but did not significantly affect withdrawal thresholds in contralateral paws (Fig. 4E). The antiallodynic effect was dose- 
dependent with an $\mathrm{ED}_{50}$ of $10.6 \mathrm{ng}$ (2.5 pmol, 95\% confidence intervals: 6.6-17.3 ng) and $\mathrm{E}_{\max }$ of $55.6 \%$ (Fig. $4 F$ ). In addition, tight ligation of peripheral L5-L6 spinal nerves produced marked ipsilateral mechanical allodynia in rats 2 weeks after surgery. Intrathecally injected exenatide $(3,10,30,100$, or $300 \mathrm{ng})$ doseand time-dependently alleviated mechanical allodynia in ipsilateral paws but did not significantly alter withdrawal thresholds in contralateral paws (Fig. $4 G$ ). The $\mathrm{ED}_{50}$ was $11.3 \mathrm{ng}$ (2.7 pmol, 95\% confidence intervals: $4.1-$ $31.1 \mathrm{ng}$ ) and $\mathrm{E}_{\max }$ was $54.3 \%$ (Fig. $4 F$ ).

Intravenous injection of streptozocin (50 $\mathrm{mg} / \mathrm{kg}$ ) in rats produced immediate and permanent high blood sugar $(>16.7$ $\mathrm{mmol} / \mathrm{L})$, and 30-50 d later resulted in painful neuropathy. The diabetic neuropathy was represented by mechanical allodynia and flinching response induced by a smaller dose of formalin $(0.2 \%)$, which was not effective in normal rats. Intrathecal injection of exenatide at a variety of doses was effective in blockade of bilateral mechanical allodynia and formalin-induced tonic flinching response in a dose-dependent manner (Fig. $4 H, I$ ), with the $\mathrm{ED}_{50}$ values of 87.1 ng (20.7 pmol, 95\% confidence intervals: $57.3-132.3 \mathrm{ng})$ and $35.0 \mathrm{ng}(8.3 \mathrm{pmol}$, 95\% confidence intervals: $25.0-49.0 \mathrm{ng}$ ) and $\mathrm{E}_{\max }$ values of $73.0 \%$ and $94.3 \%$, respectively (Fig. $4 J$ ).

In contrast, intrathecal injection of exenatide at $300 \mathrm{ng}$ did not reduce thermally evoked flicking or licking response in the rat tail immersion test or hotplate test, whereas intrathecal morphine at $10 \mu \mathrm{g}$ significantly alleviated acute nociceptive reflex responses (Fig. $4 K, L$ ). No apparent sedation or motor side effects of GLP1(7-36) and exenatide were observed during the study period. The rotarod test was conducted to further examine the possible motor side effects of exenatide. Two groups of rats ( $n=7$ or 8 in each group) received intrathecal injection of saline ( 10 $\mu \mathrm{l}$ ) or exenatide (300 ng). One hour later, the accumulated time to spend on the rotarod (running at $25 \mathrm{rpm}$ for $5 \mathrm{~min}$ ) was $272.0 \pm 18.5$ and $294.3 \pm 5.7 \mathrm{~s}$ in saline- and exenatide-treated rats, respectively. Our results suggest that exenatide has no negative effect on motor coordination, and further indicate that exenatide and GLP-1(7-36) produce antinociception in a variety of pain hypersensitivity models but not in acute nociceptive responses.

Exenatide and GLP-1 exert their antinociception by activation of spinal GLP-1Rs

To test whether the spinal antinociceptive effects of exenatide and GLP-1(7-36) acted via the spinal GLP-1Rs, the specific GLP-1R antagonist exendin(9-39) (Göke et al., 1993) and GLP-1R gene
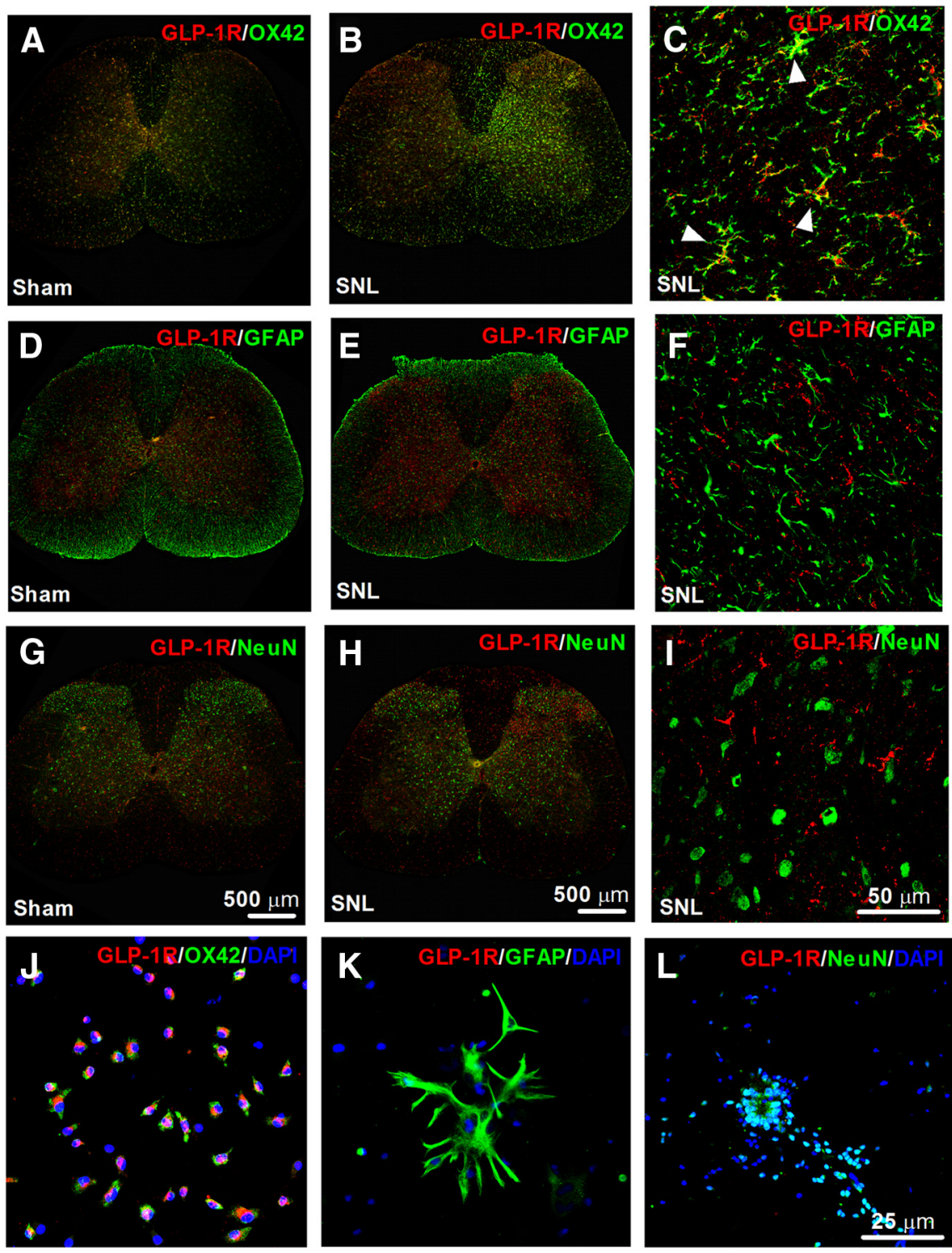

Figure 3. Representative photomicrographs of GLP-1R double fluorescence labeling with the microglial marker $0 \times 42(A-C)$, astrocytic marker GFAP $(\boldsymbol{D}-\boldsymbol{F})$, and mature neuronal marker neuronal nuclei (NeuN; $\boldsymbol{G}-\boldsymbol{I})$ in the spinal cord. Photomicrographs were taken from the entire spinal cords $(\boldsymbol{A}, \boldsymbol{B}, \boldsymbol{D}, \boldsymbol{E}, \boldsymbol{G}, \boldsymbol{H})$ and superficial dorsal horns (laminae $I-I I ; ; \boldsymbol{C}, \boldsymbol{F}, \boldsymbol{I})$ in sham and neuropathic frozen sections were obtained from the spinal lumbar enlargements 2 weeks after surgery. Arrows indicate double-labeling of GLP-1Rs in microglia $(\boldsymbol{C})$, but not in astrocytes $(\boldsymbol{F})$ or neurons $(\boldsymbol{I})$. There is increased fluorescence intensity of labeling of GLP-1R/ microglial cells $(\boldsymbol{J})$, but not on astrocytes $(\boldsymbol{K})$ or neurons $(\boldsymbol{L})$ from the spinal dorsal horn of neonatal rats. DAPI staining was also used to determine cell nuclei. Scale bars: $\boldsymbol{A}, \boldsymbol{B}, \boldsymbol{D}, \boldsymbol{E}, \boldsymbol{G}, \boldsymbol{H}, 500 \mu \mathrm{m} ; \boldsymbol{C}, \boldsymbol{F}, \boldsymbol{I}, 50 \mu \mathrm{m} ; \boldsymbol{J}-\boldsymbol{L}, 25 \mu \mathrm{m}$.

silencer (siRNA/GLP-1R) (Yin et al., 2010) were used. We first tested whether intrathecal injection of the siRNA/GLP-1R blocked spinal and dorsal root ganglial GLP-1R expression and exenatide antinociception. As shown in Figure $5 A$, multidaily intrathecal injections of the siRNA/GLP-1R $(5 \mu \mathrm{g} / \mathrm{d})$ for $7 \mathrm{~d}$ significantly reduced spinal GLP-1R gene expression measured by real-time qPCR by $57.5 \%$ and $55.6 \%$, respectively, compared with the vehicle control or nonspecific oligonucleotide control. The same comparison also showed that siRNA/GLP-1R significantly reduced GLP-1R protein expression measured by Western blotting by $69.2 \%$ or $66.2 \%$, respectively (Fig. $5 B, C$ ). In contrast, the 7-d intrathecal siRNA/GlP-1R did not reduce GLP-1R protein expression in the dorsal root ganglia (Fig. 5D). At the behav- 


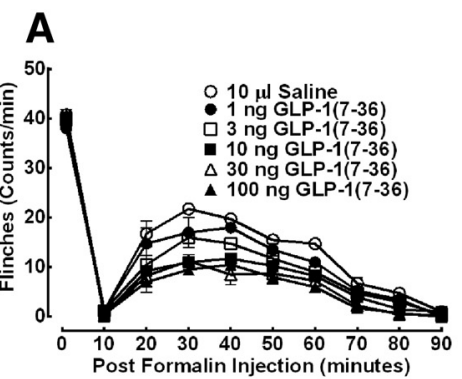

D
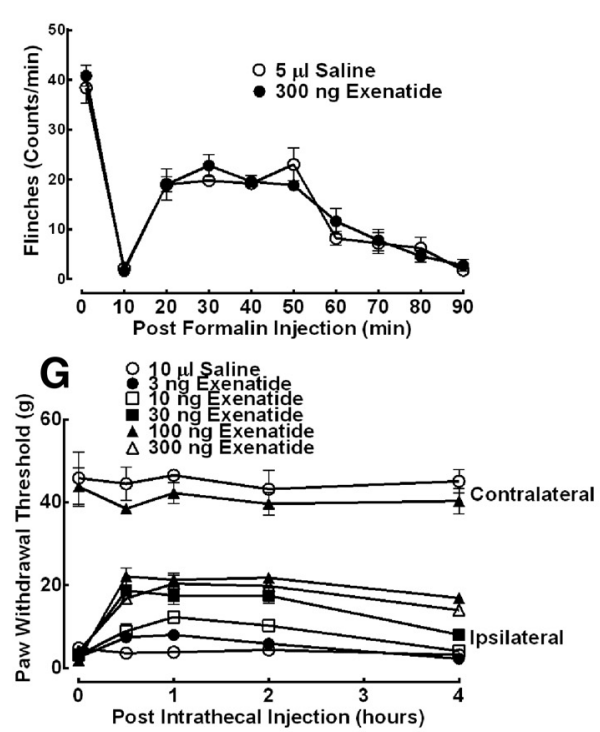

$E D_{50}(n g) E_{\max }(\%)$

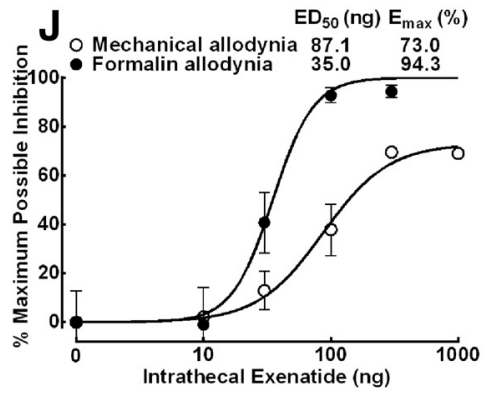

B
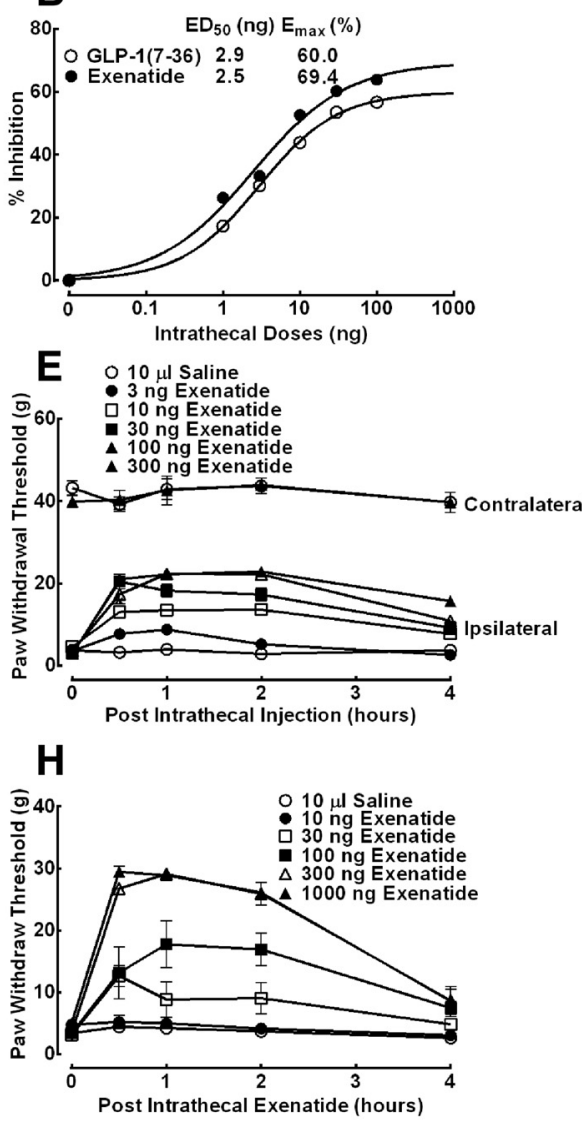

K

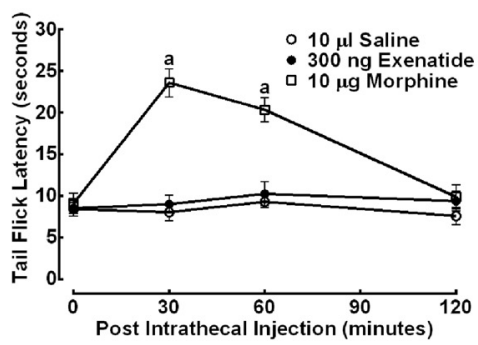

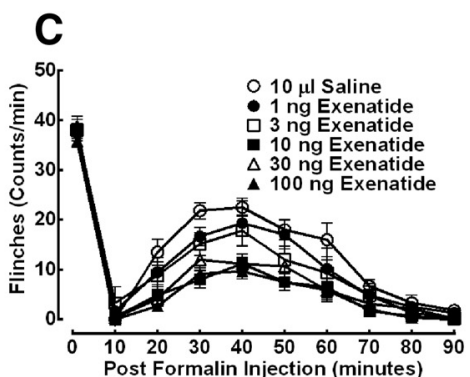
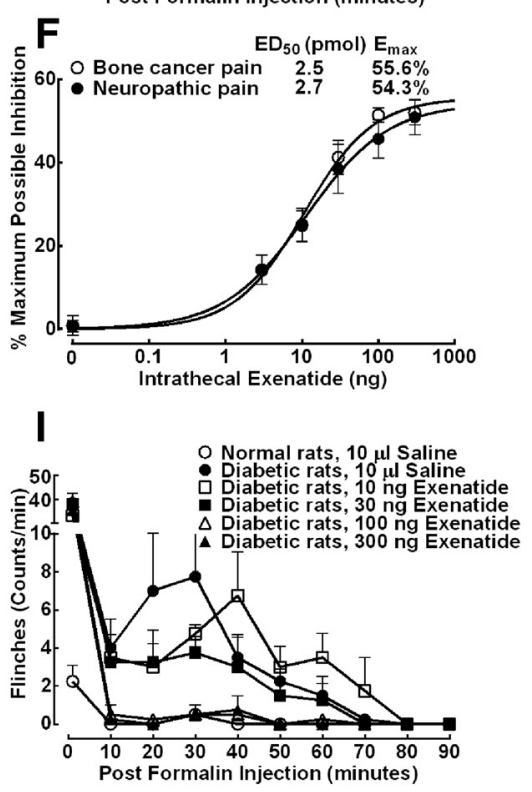

$\mathbf{L}$

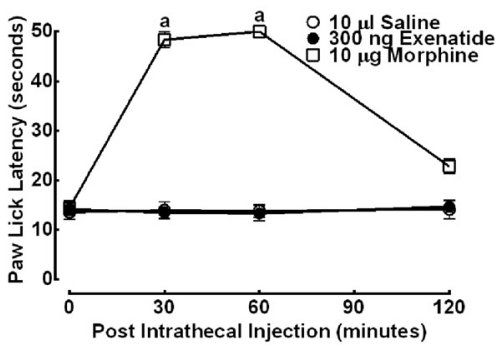

Figure 4. Effects of intrathecal and intracerebroventricular single injection of GLP-1(7-36) and exenatide on formalin-induced flinching response $(\boldsymbol{A}-\boldsymbol{D})$, bone cancer-induced mechanical allodynia $(\boldsymbol{E}, \boldsymbol{F})$, spinal nerve ligation-induced mechanical allodynia $(\boldsymbol{F}, \boldsymbol{G})$, diabetes-induced mechanical allodynia $(\boldsymbol{H}, \boldsymbol{J})$, and formalin-induced flinching response $(\boldsymbol{I}, \boldsymbol{J})$, and thermally evoked nociceptive reflex responses in the tail immersion test $(\boldsymbol{K})$ and hotplate test $(\boldsymbol{L})$ in rats. Dose-response analyses of intrathecal injection of GLP-1(7-36) and exenatide on formalin-induced tonic flinching response $(\boldsymbol{B})$, bone cancer- and nerve injury-induced mechanical allodynia $(\boldsymbol{F})$, and diabetic mechanical and formalin-induced flinching response $(\boldsymbol{J})$, best fitted by the nonlinear least-squares method. For the formalin test, naive and diabetic rats ( $\sim 30-50 \mathrm{~d}$ after intravenous injection of $50 \mathrm{mg} / \mathrm{kg}$ streptozocin) received intrathecal injection of saline, GLP-1(7-36), or exenatide 30 min before paw injection of $50 \mu l$ of $5 \%$ or $0.2 \%$ formalin, respectively. Nociceptive behavior was quantified by counting the number of formalin-injected paw flinches in 1 min epochs. For the bone cancer-, peripheral nerve injury-, and diabetes-induced mechanical allodynia, the paw withdrawal thresholds were measured by electronic von Frey filaments $\sim 14-50 \mathrm{~d}$ after tibia implantation of Walker 256 cancer cells, tight ligation of $L 5-\mathrm{L} 6$ spinal nerves, and intravenous injection of streptozocin $(50 \mathrm{mg} / \mathrm{kg}$ ), respectively. Data are mean $\pm S E M$ ( $n=6$ in each group). a Statistical significance compared with the saline control group ( $p<0.05$ by two-way ANOVA followed by post hoc Student-Newman-Keuls test).

ior level, multidaily intrathecal injections of siRNA/GLP-1R completely prevented exenatide antinociception in formalininduced tonic flinching response (Fig. 5E,F).

We further tested the blockade effect of exendin(9-39) on exenatide and GLP-1(7-36) antinociception in the formalin test. Given intrathecally, exendin(9-39) (15 $\mu \mathrm{g})$ alone did not affect either $5 \%$ (Fig. $5 G, H$ ) or $1 \%$ (Fig. $5 I$ ) formalin-induced acute or tonic flinching response in rats. Exendin $(9-39)(0.1-15 \mu \mathrm{g})$ reduced exenatide antinociception in a dose-dependent manner with complete prevention at $2 \mu \mathrm{g}$ (Fig. 5G,H). Exendin(9-39) at $2 \mu \mathrm{g}$ also completely blocked the antinociceptive effect of GLP-
1(7-36) in rats (Fig. 5J,K). More importantly, intrathecal exen$\operatorname{din}(9-39)(1 \mu \mathrm{g})$ completely prevented the antinociceptive effect of exenatide $(100 \mu \mathrm{g} / \mathrm{kg})$ given subcutaneously on formalininduce tonic flinching response in mice (instead of rats, as systemic exenatide cannot be given in such a high dose in rats because of the sympathetic discharge) (Pérez-Tilve et al., 2010) (Fig. 5L). All these results, together with Figure $4 D$ in which intraventricular injection of exenatide did not produce antinociception and with Figure 5D in which intrathecal siRNA/GLP-1R did not reduce dorsal root ganglial GLP-1R expression, indicate 

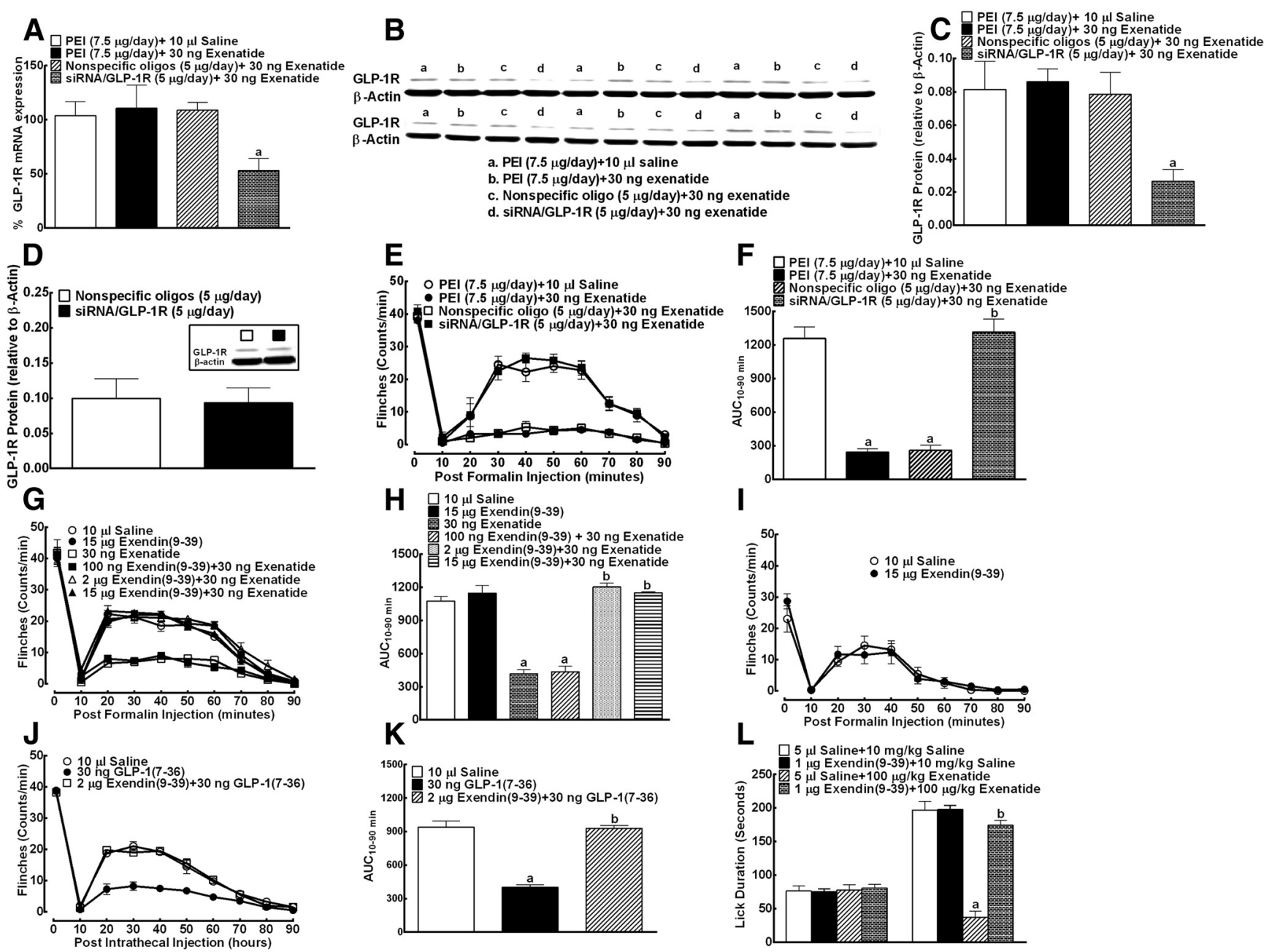

Figure 5. Effects of 7 day intrathecal injections of the GLP-1R gene silencer siRNA/GLP-1R on spinal GLP-1R gene expression (relative to gapdh) $(\boldsymbol{A})$, spinal $(\boldsymbol{B}, \boldsymbol{C})$, and dorsal root ganglial ( $\boldsymbol{D}$, with representative gels as in the inset) GLP-1R protein expression (relative to $\beta$-actin) and formalin-induced flinching responses $(\boldsymbol{E}, \boldsymbol{F})$ in rats. The vehicle PEl (7.5 $\mu \mathrm{g})$ control group, nonspecific oligoneucleotides (oligo, $5 \mu \mathrm{g}$ ) control group, and siRNA/GLP-1R $(5 \mu \mathrm{g})$ group were multidaily intrathecally injected for $7 \mathrm{~d}$ in rats. On the eight day, rats received a single intrathecal injection of saline $(10 \mu \mathrm{l})$ or exenatide $(30 \mathrm{ng})$ before $5 \%$ formalin challenge. Nociceptive behavior was quantified by counting the number of paw flinches in 1 min epochs. For the GLP-1R expression study, homogenates were obtained from spinal lumbar enlargements or dorsal rood ganglia immediately after the completion of the behavior tests. Blockade effects of intrathecal injection of the specific GLP-1R antagonist exendin(9-39) on antinociceptive effects of GLP-1(7-36) and exenatide in the rat and mouse formalin test (G- $\mathbf{L}$ ). Rats and mice received two intrathecal treatments 30 min before subcutaneous injection of 10 or $50 \mu \mathrm{l}$ of $1 \%$ or $5 \%$ formalin. The cumulated licking/biting duration from 0 to 5 min and 20 to 40 min in mice after formalin injection represented acute nociception and tonic hyperalgesia, respectively. Data are mean \pm SEM ( $n=6$ in each group). ${ }^{\mathrm{a}, \mathrm{b}}$ Statistical significance compared with the vehicle control and the exenatide or GLP-1(7-36) group, respectively ( $p<0.05$ by one-way ANOVA followed by post hoc Student-Newman-Keuls test).

that the spinal cord is a primary site responsible for GLP-1R agonism-induced antinociception.

Activation of spinal microglial GLP-1Rs releases $\boldsymbol{\beta}$-endorphin $\beta$-Endorphin, an endogenous opioid peptide neurotransmitter that specifically activates opioid receptors located on neurons (Bach, 1997; Petraschka et al., 2007), is produced mainly by the pituitary gland and hypothalamus (Loh et al., 1976; Fichna et al., 2007). $\beta$-Endorphin is also synthesized and released by cultured microglia (but not macrophages) in response to corticotropin releasing hormone (Sacerdote et al., 1993). In our preliminary study, the specific opioid receptor antagonist naloxone (more selective to $\mu$-opioid receptors) completely blocked exenatide antinociception in the mouse formalin test. Thus, we tested the hypothesis that activation of spinal dorsal horn microglial GLP1 Rs releases $\beta$-endorphin, which in turn activates opioid receptors to produce antinociception. First, we tested whether minocycline blocked exenatide antinociception in neuropathic rats 2 weeks after surgery. Minocycline is an inhibitor of microglia (but not neurons) through its prevention of nuclear factor $\kappa \mathrm{B}$ translocation to its nuclear promoter via p38 mitogen-activated protein kinase (MAPK), with its inhibitory effect lasting for at least 24 h (Raghavendra et al., 2003; Hua et al., 2005; Mei et al., 2011). Subsequent intrathecal injection of both exenatide (100 ng) and morphine $(10 \mu \mathrm{g})$ produced marked and reversible antiallodynia in ipsilateral paws. Morphine but not exenatide had a mild antinociception in contralateral paws in neuropathic rats. Spinal minocycline was not effective in alleviating established mechanical allodynia, which was consistent with previous findings (Raghavendra et al., 2003; Hua et al., 2005; Mei et al., 2011). However, minocycline completely prevented exenatide antiallodynia. In contrast, minocycline did not affect morphine antinociception, which is known to be produced by activation of opioid receptors located on neurons (Fig. 6A).

In addition, intrathecal injection of the antiserum (1:100 and $1: 10$ ) dose-dependently reduced exenatide antiallodynia in neu- 
A

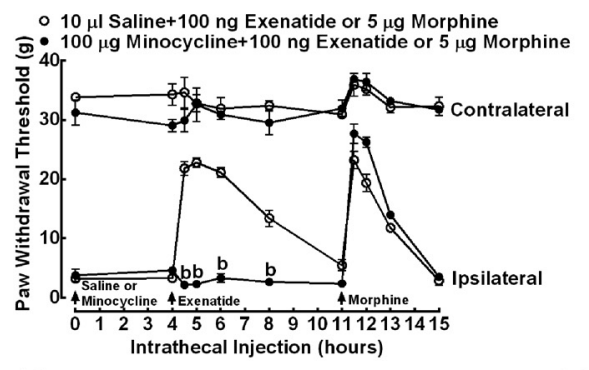

D
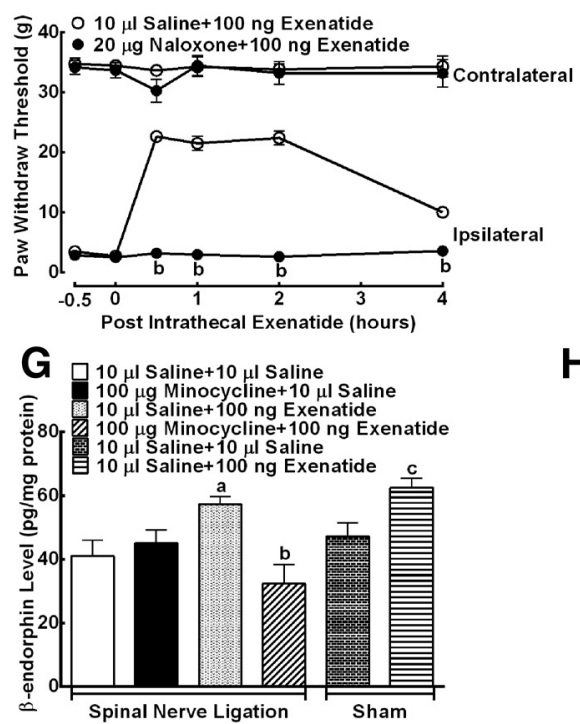

B

H

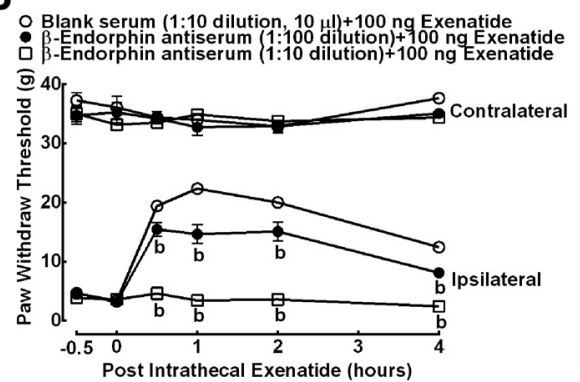

E
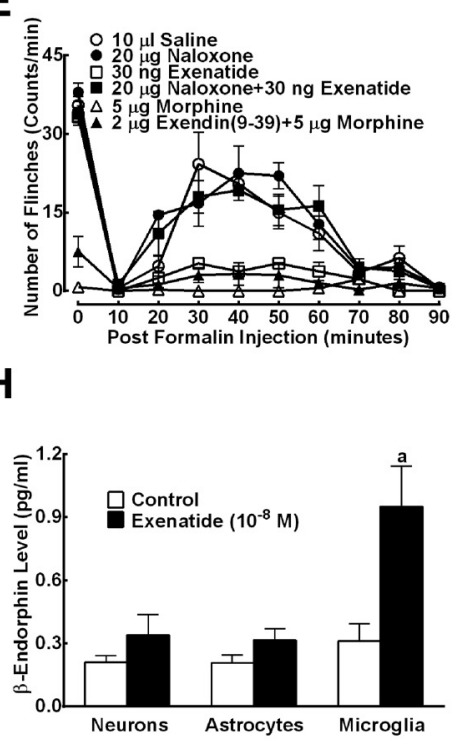

\section{C}
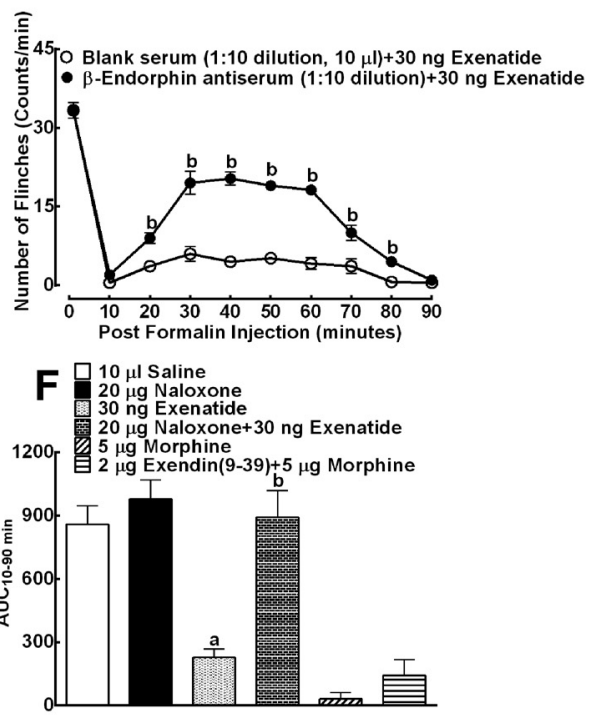

Figure 6. Effects of intrathecal injection of the microglial inhibitor minocycline $(\boldsymbol{A})$, specific $\beta$-endorphin antiserum $(\boldsymbol{B}, \boldsymbol{C})$, and specific opioid receptor antagonist naloxone $(\boldsymbol{D}-\boldsymbol{F})$ on spinal exenatide antinociception in peripheral neuropathy-induced mechanical allodynia or formalin-induced hyperalgesia in rats. For neuropathic rats, paw withdrawal thresholds were measured by electronic von Frey filaments 2 weeks after tight ligation of $L 5-L 6$ spinal nerves. For the formalin test, rats received two intrathecal treatments 30 min before subcutaneous injection of $50 \mu l$ of $5 \%$ formalin. Nociceptive behavior was quantified by counting the number of the formalin-injected paw flinches in 1 min epochs. Blank serum as the negative control was from a healthy rabbit without any treatment. $\mathbf{G}$, Effects of intrathecal injection of exenatide on the spinal $\beta$-endorphin level in neuropathic rats and sham rats. Minocycline (100 $\mu \mathrm{g})$ was intrathecally injected $4 \mathrm{~h}$ earlier before exenatide treatment. Ipsilateral spinal lumbar enlargements were obtained $1 \mathrm{~h}$ after exenatide injection in neuropathic rats. $\boldsymbol{H}$, Effects of exenatide $\left(10^{-8} \mathrm{M}\right)$ on $\beta$-endorphin release at $2 \mathrm{~h}$ after application in primarily cultured spinal microglia, astrocytes, and neurons from the spinal dorsal horn of neonatal rats. $\beta$-Endorphin levels in the spinal cord homogenates and culture media were determined by a specific fluorescent immunoassay kit. Data are means \pm SEM $\left(n=6\right.$ in each group). ${ }^{\text {a,b }}$ Statistical significance compared with the saline control and the exenatide group, respectively ( $p<0.05$ by one-way or two-way ANOVA followed by post hoc Student-Newman-Keuls test). 'Statistical significance compared with the saline control in sham rats ( $p<0.05$ by oneor two-way ANOVA followed by post hoc Student-Newman-Keuls test).

ropathic rats compared with the blank rabbit serum, although it did not alter baseline mechanical thresholds (Fig. 6B). The complete blockade effect of the $\beta$-endorphin on exenatide antinociception was also confirmed in the rat formalin test (Fig. 6C). Moreover, the specific opioid receptor antagonist naloxone (20 $\mu \mathrm{g})$ given intrathecally did not significantly change baseline paw withdrawal thresholds in ipsilateral paws in neuropathic rats but completely prevented spinal exenatide antiallodynia (Fig. 6D). As shown in Figure $6 E, F$, the complete blockade effect of naloxone on exenatide antinociception was also confirmed in the rat formalin test. On the other hand, intrathecally the GLP-1 receptor antagonist exendin(9-39) did not alter spinal morphine antinociception both in the acute and tonic phases.

Finally, the stimulating effects of exenatide on $\beta$-endorphin release were directly measured in the spinal cord and primarily cultured neuronal and glial cells. Ipsilateral spinal lumbar enlargements were obtained from spinal nerve ligation-induced neuropathic rats $1 \mathrm{~h}$ after exenatide injection, and the spinal $\beta$-endorphin level was measured. As exhibited in Figure $6 G$, intrathecal injection of exenatide significantly increased $\beta$-endorphin level in the ipsilateral spinal cord by $39.5 \%$. Minocycline did not significantly alter the baseline level of $\beta$-endorphin but completely prevented exenatide-induced increase in $\beta$-endorphin level in the spinal cord. In sham rats, exenatide also significantly increased ipsilateral spinal $\beta$-endorphin level by $32.4 \%$. Furthermore, spinal microglia, astrocytes, and neurons were isolated from the spinal dorsal horn of neonatal rats. As shown in Figure $6 \mathrm{H}$, exenatide at $10^{-8} \mathrm{M}$ at $2 \mathrm{~h}$ after application significantly released $\beta$-endorphin from microglia into the culture media by approximately twofold. Exenatide did not release $\beta$-endorphin from cultured neurons or astrocytes. Our results indicate that GLP-1R agonism stimulates spinal dorsal horn microglial cells to release $\beta$-endorphin, which in turn activates opioid receptors located on neurons to produce antinociception.

\section{Discussion}

For the first time, we demonstrate that exogenous exenatide and GLP-1, by activation of spinal dorsal horn GLP-1Rs, effectively block broad pain hypersensitivity states without affecting acute nociceptive reflex behaviors. Their antinociceptive potencies 
$\left(\mathrm{ED}_{50}\right)$ are ranked as follows: the most effective $=$ formalininduced tonic flinching response $>$ neuropathy-induced mechanical allodynia $=$ bone cancer-induced mechanical allodynia $>$ diabetes-induced allodynia $>$ acute nociceptive responses $=$ ineffective (Fig. 4). It has been shown that formalininduced tonic (but not acute nociception) hyperalgesia (Dickenson and Sullivan, 1987; Coderre et al., 1990), neuropathic pain (Latremoliere and Woolf, 2009), bone cancer pain (Honore et al., 2000; Luger et al., 2002; Yanagisawa et al., 2010), and painful diabetic neuropathy (Surcheva et al., 2009; Rondón et al., 2010; Talbot et al., 2010) share a common mechanism of central sensitization, with characteristic neuronal plastic changes within the spinal dorsal horn. Our results suggest that activation of GLP-1Rs is specifically effective in alleviation of allodynia and hyperalgesia in a variety of animal models in which central sensitization is involved.

Preproglucagon expression is found in the solitary tract nucleus and the brainstem, and post-translational processing of proglucagon leads to production of GLP-1 (Kreymann et al., 1989; Larsen et al., 1997). GLP-1-immunoreactive fibers in the hypothalamus originated from solitary tract nucleus cell bodies innervate the hypothalamus, paraventricular and dorsomedial nuclei, arcuate nuclei and subfornical organ, as well as in extrahypothalamic areas, such as thalamic and cortical areas (Larsen et al., 1997; Cabou and Burcelin, 2011). In the brainstem, fibers project toward reticular formation and the spinal cord (Jin et al., 1988; Merchenthaler et al., 1999). Although there are little data revealing the origin of GLP-1 in the spinal cord, the fact that exogenous exenatide and GLP-1 lead to spinal antinociception prompted us to explore whether the endogenous GLP-1 system in the spinal cord mediates antinociception. Our data indicate that either blockade of GLP-1Rs or knockdown of GLP-1R gene does not affect formalin flinching responses (Fig. 5). The finding is further supported by our unpublished results in which intrathecal injection of specific and potent DPP-4 inhibitor sitagliptin was not effective in alleviating formalin-induced acute or tonic flinching response. Our results suggest that, in contrast to the positive endogenous control of peripheral GLP-1 in mediating insulin release and glucoregulation (Green et al., 2005), the endogenous GLP-1 system in the spinal cord does not mediate tonic antinociception, presumably because of lower concentrations of GLP-1. Further studies are warranted to examine the distribution and level of GLP-1 in the spinal cord, particularly in the dorsal horn.

We further identify that $\beta$-endorphin release and subsequent activation of opioid receptors are the mechanism for GLP-1R agonism to produce antinociception in pain hypersensitivity states. However, spinal exenatide also significantly releases $\beta$-endorphin from sham rats by almost the same degree but does not exhibit antinociception in the acute nociceptive responses. This discrepancy may result from the lower sensitivity to exogenous and endogenous opioids in the normal nociceptive sensitivity condition in which central sensitization is not involved. Endogenous $\beta$-endorphin released $(\sim 25 \mathrm{pg} / \mathrm{mg}$ protein) may therefore not be able to produce efficacious antinociception. It is true that morphine blocked formalin-induced tonic flinching response $\left(\mathrm{ED}_{50}: 0.5 \mathrm{mg} / \mathrm{kg}\right.$, $95 \%$ confidence limit: $0.4-0.8 \mathrm{mg} / \mathrm{kg}$ ) more potently than acute nociceptive response $\left(\mathrm{ED}_{50}: 1.6 \mathrm{mg} / \mathrm{kg}, 95 \%\right.$ confidence limit: $1.1-2.8 \mathrm{mg} / \mathrm{kg}$ ) (Gong et al., 2012). It is also true that morphine was more effective in reducing mechanical allodynia in ipsilateral paws than mechanical withdrawal thresholds in contralateral paws in neuropathic rats (present study) and bone cancer pain rats (Huang et al., 2012). On the other hand, intrathecal administration of exogenous $\beta$-endorphin at doses of $1-10 \mu \mathrm{g}$ is antinociceptive in the normal nociceptive sensitivity state (Hong et al., 1993; Tseng et al., 1995). This is probably because of its much higher concentrations in the spinal cord ( $\sim 25-250 \mathrm{ng} / \mathrm{mg}$ protein), in sharp contrast to exenatidestimulated release of endogenous $\beta$-endorphin $(\sim 25 \mathrm{pg} / \mathrm{mg}$ protein). The delivered exogenous $\beta$-endorphin level in the spinal cord is estimated from its doses of $1-10 \mu \mathrm{g}$ and a simply equal distribution in the spinal cord mass and CSF of $\sim 1 \mathrm{~g}$ (Jimenez Hamann et al., 2003; McIlwain et al., 2004). Nevertheless, spinal GLP-1Rs may represent a potential therapeutic target molecule for the management of chronic pain, particularly refractory cancer pain, neuropathic pain, and painful diabetic neuropathy. The notion is further supported by the following two findings: (1) specific cellular distribution: GLP-1Rs are specifically expressed on microglial cells rather than astrocytes or neurons; and (2) disease induction: GLP-1Rs are profoundly upregulated accompanying microglial proliferation and hypertrophy after peripheral nerve injury.

GLP-1Rs are identified to be specifically expressed on spinal dorsal horn microglial cells. Cumulative evidence highlights that spinal microglia are activated and upregulated in the spinal dorsal horn after inflammatory insult, peripheral nerve injury, and diabetes, and play a primary influence on neural transmission and plasticity, particularly induction of central sensitization-involved chronic pain (Hua et al., 2005; Gosselin et al., 2010; Talbot et al., 2010). Reactive microglial cells undergo changes in phenotype including activation of the p38-MAPK signaling pathway in chronic neuropathic pain, which can be blocked by minocycline (Hua et al., 2005). The pathway is essential for synthesis and release of pronociceptive cytokines and neurotrophins, such as BDNF and TNF- $\alpha$, that reinforce nociception by reducing descending inhibition, sensitizing spinal neurons, and activating astrocytes (Gosselin et al., 2010). However, there were recent reports that M1- and M2-type of microglial cells were in the ischemic brain area during stroke and had differential roles in neuroprotection: M1 microglial cells were neural destructive, whereas M2 microglial cells were protective (Hu et al., 2012). It is therefore possible that spinal microglial cells may also have dual and opposing roles in pain processing: proalgesia and analgesia. Our results indeed suggest that activation of spinal dorsal horn microglial GLP-1Rs releases $\beta$-endorphin, in contrast to inflammatory cytokines and neurotrophins, and produces antinociception in a variety of pain hypersensitivity states.

\section{References}

Alvarez E, Martínez MD, Roncero I, Chowen JA, García-Cuartero B, Gispert JD, Sanz C, Vázquez P, Maldonado A, de Cáceres J, Desco M, Pozo MA, Blázquez E (2005) The expression of GLP-1 receptor mRNA and protein allows the effect of GLP-1 on glucose metabolism in the human hypothalamus and brainstem. J Neurochem 92:798-806. CrossRef Medline

Avila-Martin G, Galan-Arriero I, Gómez-Soriano J, Taylor J (2011) Treatment of rat spinal cord injury with the neurotrophic factor albumin-oleic acid: translational application for paralysis, spasticity and pain. PLoS One 6:e26107. CrossRef Medline

Bach FW (1997) Beta-endorphin in the brain: a role in nociception. Acta Anaesthesiol Scand 41:133-140. CrossRef Medline

Baggio LL, Drucker DJ (2007) Biology of incretins: GLP-1 and GIP. Gastroenterology 132:2131-2157. CrossRef Medline

Beinborn M, Worrall CI, McBride EW, Kopin AS (2005) A human glucagon-like peptide-1 receptor polymorphism results in reduced agonist responsiveness. Regul Pept 130:1-6. CrossRef Medline

Bullock BP, Heller RS, Habener JF (1996) Tissue distribution of messenger 
ribonucleic acid encoding the rat glucagon-like peptide-1 receptor. Endocrinology 137:2968-2978. CrossRef Medline

Cabou C, Burcelin R (2011) GLP-1, the gut-brain, and brain-periphery axes. Rev Diabet Stud 8:418-431. CrossRef Medline

Chen XL, Li XY, Qian SB, Wang YC, Zhang PZ, Zhou XJ, Wang YX (2012) Down-regulation of spinal $\mathrm{D}$-amino acid oxidase expression blocks formalin-induced tonic pain. Biochem Biophys Res Commun 421:501507. CrossRef Medline

Coderre TJ, Vaccarino AL, Melzack R (1990) Central nervous system plasticity in the tonic pain response to subcutaneous formalin injection. Brain Res 535:155-158. CrossRef Medline

Coopman K, Huang Y, Johnston N, Bradley SJ, Wilkinson GF, Willars GB (2010) Comparative effects of the endogenous agonist glucagon-like peptide-1 (GLP-1)-(7-36) amide and the small-molecule ago-allosteric agent "compound 2" at the GLP-1 receptor. J Pharmacol Exp Ther 334: 795-808. CrossRef Medline

Courteix C, Eschalier A, Lavarenne J (1993) Streptozocin-induced diabetic rats: behavioural evidence for a model of chronic pain. Pain 53:81-88. CrossRef Medline

Davis JA, Singh S, Sethi S, Roy S, Mittra S, Rayasam G, Bansal V, Sattigeri J, Ray A (2010) Nature of action of Sitagliptin, the dipeptidyl peptidase-IV inhibitor in diabetic animals. Indian J Pharmacol 42:229-233. CrossRef Medline

Dickenson AH, Sullivan AF (1987) Subcutaneous formalin-induced activity of dorsal horn neurones in the rat: differential response to an intrathecal opiate administered pre or post formalin. Pain 30:349-360. CrossRef Medline

Eng J, Kleinman WA, Singh L, Singh G, Raufman JP (1992) Isolation and characterization of exendin-4, an exendin-3 analogue, from Heloderma suspectum venom: further evidence for an exendin receptor on dispersed acini from guinea pig pancreas. J Biol Chem 267:7402-7405. Medline

Fichna J, Janecka A, Costentin J, Do Rego JC (2007) The endomorphin system and its evolving neurophysiological role. Pharmacol Rev 59:88123. CrossRef Medline

Göke R, Fehmann HC, Linn T, Schmidt H, Krause M, Eng J, Göke B (1993) Exendin- 4 is a high potency agonist and truncated exendin-(9-39)-amide an antagonist at the glucagon-like peptide 1-(7-36)-amide receptor of insulin-secreting $\beta$-cells. J Biol Chem 268:19650-19655. Medline

Gong N, Ma AN, Zhang LJ, Luo XS, Zhang YH, Xu M, Wang YX (2011a) Site-specific PEGylation of exenatide analogues markedly improved their glucoregulatory activity. Br J Pharmacol 163:399-412. CrossRef Medline

Gong N, Gao ZY, Wang YC, Li XY, Huang JL, Hashimoto K, Wang YX (2011b) A series of D-amino acid oxidase inhibitors specifically prevents and reverses formalin-induced tonic pain in rats. J Pharmacol Exp Ther 336:282-293. CrossRef Medline

Gong N, Wang YC, Wang HL, Ma AN, Hashimoto K, Wang YX (2012) Interactions of the potent D-amino acid oxidase inhibitor CBIO with morphine in pain and tolerance to analgesia. Neuropharmacology 63: 460-468. CrossRef Medline

Gong N, Li XY, Xiao Q, Wang YX (2013) Identification of a novel spinal dorsal horn astroglial $\mathrm{D}$-amino acid oxidase-hydrogen peroxide pathway involved in morphine antinociceptive tolerance. Anesthesiology. Advance online publication. Retrieved Aug. 7, 2013. Medline

Gosselin RD, Suter MR, Ji RR, Decosterd I (2010) Glial cells and chronic pain. Neuroscientist 16:519-531. CrossRef Medline

Green BD, Irwin N, Gault VA, Bailey CJ, O'Harte FP, Flatt PR (2005) Chronic treatment with exendin(9-39)amide indicates a minor role for endogenous glucagon-like peptide-1 in metabolic abnormalities of obesity-related diabetes in ob/ob mice. J Endocrinol 185:307-317. CrossRef Medline

Gwak YS, Hulsebosch CE (2009) Remote astrocytic and microglial activation modulates neuronal hyperexcitability and below-level neuropathic pain after spinal injury in rat. Neuroscience 161:895-903. CrossRef Medline

Himeno T, Kamiya H, Naruse K, Harada N, Ozaki N, Seino Y, Shibata T, Kondo M, Kato J, Okawa T, Fukami A, Hamada Y, Inagaki N, Seino Y,Drucker DJ, Oiso Y, Nakamura J (2011) Beneficial effects of exendin-4 on experimental polyneuropathy in diabetic mice. Diabetes 60:2397-2406. CrossRef Medline

Holst JJ (2007) The physiology of glucagon-like peptide 1. Physiol Rev 87: 1409-1439. CrossRef Medline

Hong M, Sutak M, Jhamandas K (1993) Inhibition of spinal opioid antino- ciception by intrathecal $\beta$-endorphin1-27 in the rat. Br J Pharmacol 108: 1137-1142. CrossRef Medline

Honore P, Mantyh PW, Rogers SD, Schwei MJ, Salak-Johnson JL, Luger NM, Sabino MC, Clohisy DR (2000) Murine models of inflammatory, neuropathic and cancer pain each generates a unique set of neurochemical changes in the spinal cord and sensory neurons. Neuroscience 98:585598. CrossRef Medline

Hua XY, Svensson CI, Matsui T, Fitzsimmons B, Yaksh TL, Webb M (2005) Intrathecal minocycline attenuates peripheral inflammation-induced hyperalgesia by inhibiting p38 MAPK in spinal microglia. Eur J Neurosci 22:2431-2440. CrossRef Medline

Huang JL, Chen XL, Guo C, Wang YX (2012) Contributions of spinal D-amino acid oxidase to bone cancer pain. Amino Acids 43:1905-1918. CrossRef Medline

Hu X, Li P, Guo Y, Wang H, Leak RK, Chen S, Gao Y, Chen J (2012) Microglia/macrophage polarization dynamics reveal novel mechanism of injury expansion after focal cerebral ischemia. Stroke 43:3063-3070. CrossRef Medline

Jimenez Hamann MC, Tsai EC, Tator CH, Shoichet MS (2003) Novel intrathecal delivery system for treatment of spinal cord injury. Exp Neurol 182:300-309. CrossRef Medline

Jin SL, Han VK, Simmons JG, Towle AC, Lauder JM, Lund PK (1988) Distribution of glucagonlike peptide I (GLP-I), glucagon, and glicentin in the rat brain: an immunocytochemical study. J Comp Neurol 271:519-532. CrossRef Medline

Kim SH, Chuang J (1992) An experimental model for peripheral neuropathy produced by segmental spinal nerve ligation in the rat. Pain 50:355-363. Medline

Kreymann B, Ghatei MA, Burnet P, Williams G, Kanse S, Diani AR, Bloom SR (1989) Characterization of glucagon-like peptide-1-(7-36)amide in the hypothalamus. Brain Res 502:325-331. CrossRef Medline

Larsen PJ, Tang-Christensen M, Holst JJ, Orskov C (1997) Distribution of glucagon-like peptide-1 and other preproglucagon-derived peptides in the rat hypothalamus and brainstem. Neuroscience 77:257-270. CrossRef Medline

Latremoliere A, Woolf CJ (2009) Central sensitization: a generator of pain hypersensitivity by central neural plasticity. J Pain 10:895-926. CrossRef Medline

Li Y, Chigurupati S, Holloway HW, Mughal M, Tweedie D, Bruestle DA, Mattson MP, Wang Y, Harvey BK, Ray B, Lahiri DK, Greig NH (2012) Exendin-4 ameliorates motor neuron degeneration in cellular and animal models of amyotrophic lateral sclerosis. PLoS One 7:e32008. CrossRef Medline

Lindia JA, McGowan E, Jochnowitz N, Abbadie C (2005) Induction of CX3CL1 expression in astrocytes and CX3CR1 in microglia in the spinal cord of a rat model of neuropathic pain. J Pain 6:434-438. CrossRef Medline

Loh HH, Tseng LF, Wei E, Li CH (1976) $\beta$-Endorphin is a potent analgesic agent. Proc Natl Acad Sci U S A 73:2895-2898. CrossRef Medline

Lu JM, Gong N, Wang YC, Wang YX (2012) D-Amino acid oxidasemediated increase in spinal hydrogen peroxide is mainly responsible for formalin-induced tonic pain. Br J Pharmacol 165:1941-1955. CrossRef Medline

Luger NM, Sabino MA, Schwei MJ, Mach DB, Pomonis JD, Keyser CP, Rathbun M, Clohisy DR, Honore P, Yaksh TL, Mantyh PW (2002) Efficacy of systemic morphine suggests a fundamental difference in the mechanisms that generate bone cancer vs inflammatory pain. Pain 99:397-406. CrossRef Medline

Maione S, Siniscalco D, Galderisi U, de Novellis V, Uliano R, Di Bernardo G, Berrino L, Cascino A, Rossi F (2002) Apoptotic genes expression in the lumbar dorsal horn in a model neuropathic pain in rat. Neuroreport 13:101-106. CrossRef Medline

Mao-Ying QL, Zhao J, Dong ZQ, Wang J, Yu J, Yan MF, Zhang YQ, Wu GC, Wang YQ (2006) A rat model of bone cancer pain induced by intra-tibia inoculation of Walker 256 mammary gland carcinoma cells. Biochem Biophys Res Commun 345:1292-1298. CrossRef Medline

McIlwain DL, Hoke VB, Kopchick JJ, Fuller CR, Lund PK (2004) Differential inhibition of postnatal brain, spinal cord and body growth by a growth hormone antagonist. BMC Neurosci 5:6. CrossRef Medline

Mei XP, Xu H, Xie C, Ren J, Zhou Y, Zhang H, Xu LX (2011) Post-injury administration of minocycline: an effective treatment for nerve-injury induced neuropathic pain. Neurosci Res 70:305-312. CrossRef Medline

Merchenthaler I, Lane M, Shughrue P (1999) Distribution of pre-pro- 
glucagon and glucagon-like peptide-1 receptor messenger RNAs in the rat central nervous system. J Comp Neurol 403:261-280. CrossRef Medline

Morgado C, Silva L, Pereira-Terra P, Tavares I (2011) Changes in serotoninergic and noradrenergic descending pain pathways during painful diabetic neuropathy: the preventive action of IGF1. Neurobiol Dis 43:275-284. CrossRef Medline

Nakamura Y, Morioka N, Abe H, Zhang FF, Hisaoka-Nakashima K, Liu K, Nishibori M, Nakata Y (2013) Neuropathic pain in rats with a partial sciatic nerve ligation is alleviated by intravenous injection of monoclonal antibody to high mobility group box-1. PLoS One. doi: 10.1371/journal.pone.0073640. CrossRef Medline

Pérez-Tilve D, González-Matías L, Aulinger BA, Alvarez-Crespo M, GilLozano M, Alvarez E, Andrade-Olivie AM, Tschöp MH, D’Alessio DA, Mallo F (2010) Exendin-4 increases blood glucose levels acutely in rats by activation of the sympathetic nervous system. Am J Physiol Endocrinol Metab 298:E1088-E1096. CrossRef Medline

Perry T, Haughey NJ, Mattson MP, Egan JM, Greig NH (2002) Protection and reversal of excitotoxic neuronal damage by glucagon-like peptide-1 and exendin-4. J Pharmacol Exp Ther 302:881-888. CrossRef Medline

Perry T, Lahiri DK, Sambamurti K, Chen D, Mattson MP, Egan JM, Greig NH (2003) Glucagon-like peptide-1 decreases endogenous amyloid- $\beta$ peptide (Abeta) levels and protects hippocampal neurons from death induced by Abeta and iron. J Neurosci Res 72:603-612. CrossRef Medline

Petraschka M, Li S, Gilbert TL, Westenbroek RE, Bruchas MR, Schreiber S, Lowe J, Low MJ, Pintar JE, Chavkin C (2007) The absence of endogenous $\beta$-endorphin selectively blocks phosphorylation and desensitization of $\mu$ opioid receptors following partial sciatic nerve ligation. Neuroscience 146:1795-1807. CrossRef Medline

Raghavendra V, Tanga F, DeLeo JA (2003) Inhibition of microglial activation attenuates the development but not existing hypersensitivity in a rat model of neuropathy. J Pharmacol Exp Ther 306:624-630. CrossRef Medline

Ramos LS, Zippin JH, Kamenetsky M, Buck J, Levin LR (2008) Glucose and GLP-1 stimulate cAMP production via distinct adenylyl cyclases in INS-1E insulinoma cells. J Gen Physiol 132:329-338. CrossRef Medline

Roger B, Papin J, Vacher P, Raoux M, Mulot A, Dubois M, Kerr-Conte J, Voy BH, Pattou F, Charpentier G, Jonas JC, Moustaïd-Moussa N, Lang J (2011) Adenylyl cyclase 8 is central to glucagon-like peptide 1 signalling and effects of chronically elevated glucose in rat and human pancreatic beta cells. Diabetologia 54:390-402. CrossRef Medline

Rondón LJ, Privat AM, Daulhac L, Davin N, Mazur A, Fialip J, Eschalier A, Courteix C (2010) Magnesium attenuates chronic hypersensitivity and spinal cord NMDA receptor phosphorylation in a rat model of diabetic neuropathic pain. J Physiol 588:4205-4215. CrossRef Medline

Sacerdote P, Denis-Donini S, Paglia P, Granucci F, Panerai AE, RicciardiCastagnoli P (1993) Cloned microglial cells but not macrophages synthesize $\beta$-endorphin in response to CRH activation. Glia 9:305-310. CrossRef Medline

Saper CB (1996) Any way you cut it: a new journal policy for the use of unbiased counting methods. J Comp Neurol 364:5. CrossRef Medline
Scholz J, Broom DC, Youn DH, Mills CD, Kohno T, Suter MR, Moore KA, Decosterd I, Coggeshall RE, Woolf CJ (2005) Blocking caspase activity prevents transsynaptic neuronal apoptosis and the loss of inhibition in lamina II of the dorsal horn after peripheral nerve injury. J Neurosci 25:7317-7323. CrossRef Medline

Surcheva SK, Surchev LK, Milev MD, Kasakov LN, Vlaskovska MV (2009) Possible involvement of spinal glial cells and glutamatergic transmission in streptozotocin-induced neuropathic pain in rats. J Biomed Clin Res 2:26-30.

Syme CA, Zhang L, Bisello A (2006) Caveolin-1 regulates cellular trafficking and function of the glucagon-like peptide 1 receptor. Mol Endocrinol 20:3400-3411. CrossRef Medline

Talbot S, Chahmi E, Dias JP, Couture R (2010) Key role for spinal dorsal horn microglial kinin B1 receptor in early diabetic pain neuropathy. J Neuroinflammation 7:36. CrossRef Medline

Teramoto S, Miyamoto N, Yatomi K, Tanaka Y, Oishi H, Arai H, Hattori N, Urabe T (2011) Exendin-4, a glucagon-like peptide-1 receptor agonist, provides neuroprotection in mice transient focal cerebral ischemia. J Cereb Blood Flow Metab 31:1696-1705. CrossRef Medline

Tornehave D, Kristensen P, Rømer J, Knudsen LB, Heller RS (2008) Expression of the GLP-1 receptor in mouse, rat, and human pancreas. J Histochem Cytochem 56:841-851. CrossRef Medline

Tseng LF, Henneberry B, Collins KA (1995) The antinociception induced by $\beta$-endorphin administered intrathecally is mediated by the activation of $\mu$ - and $\kappa$-opioid receptors in the rat. Naunyn Schmiedebergs Arch Pharmacol 351:464-468. Medline

Vahl TP, Tauchi M, Durler TS, Elfers EE, Fernandes TM, Bitner RD, Ellis KS, Woods SC, Seeley RJ, Herman JP, D’Alessio DA (2007) Glucagon-like peptide-1 (GLP-1) receptors expressed on nerve terminals in the portal vein mediate the effects of endogenous GLP-1 on glucose tolerance in rats. Endocrinology 148:4965-4973. CrossRef Medline

Villanueva-Peñacarrillo ML, Delgado E, Vicent D, Mérida E, Alcántara AI, Valverde I (1995) GLP-1(7-36)amide binding in skeletal muscle membranes from streptozotocin diabetic rats. Endocrine 3:685-687. CrossRef Medline

Wang YX, Pang CC (1993) Functional integrity of the central and sympathetic nervous systems is a prerequisite for pressor and tachycardic effects of diphenyleneiodonium, a novel inhibitor of nitric oxide synthase. J Pharmacol Exp Ther 265:263-272. Medline

Yanagisawa Y, Furue H, Kawamata T, Uta D, Yamamoto J, Furuse S, Katafuchi T, Imoto K, Iwamoto Y, Yoshimura M (2010) Bone cancer induces a unique central sensitization through synaptic changes in a wide area of the spinal cord. Mol Pain 6:38. CrossRef Medline

Yin F, Liu JH, Zheng XX, Guo LX (2010) GLP-1 receptor plays a critical role in geniposide-induced expression of heme oxygenase-1 in PC12 cells. Acta Pharmacol Sin 31:540-545. CrossRef Medline

Zhao WJ, Gao ZY, Wei H, Nie HZ, Zhao Q, Zhou XJ, Wang YX (2010) Spinal $\mathrm{D}$-amino acid oxidase contributes to neuropathic pain in rats. J Pharmacol Exp Ther 332:248-254. CrossRef Medline 